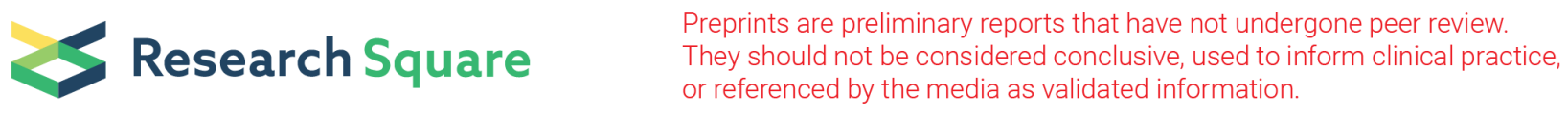

\title{
The Molecular Mass and Isoelectric Point of Plant Proteomes
}

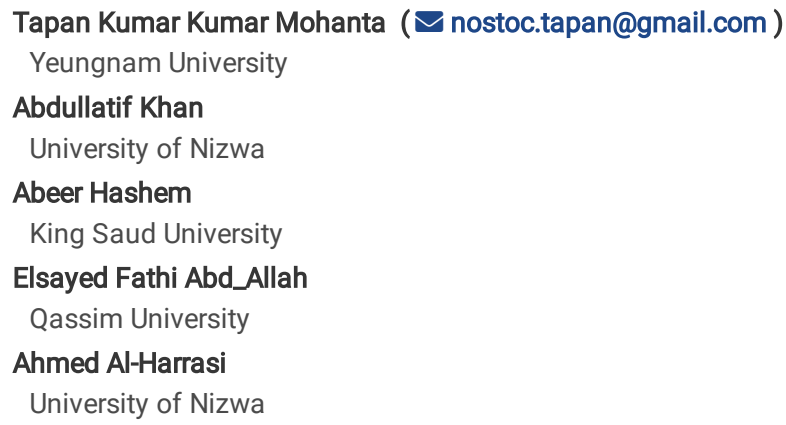

\section{Research article}

Keywords: Proteome, amino acids, Isoelectric point, Molecular weight, Selenocysteine, Pyrrolysine

Posted Date: April 26th, 2019

DOI: https://doi.org/10.21203/rs.2.9382/v1

License: (c) (i) This work is licensed under a Creative Commons Attribution 4.0 International License. Read Full License

Version of Record: A version of this preprint was published at BMC Genomics on August 5th, 2019. See the published version at https://doi.org/10.1186/s12864-019-5983-8. 


\section{Abstract}

A proteomic analysis of proteomes from 145 plant species revealed a pl range of 1.99 (epsin) to 13.96 (hypothetical protein). The molecular mass of the plant proteins ranged from 0.54 to $2236.8 \mathrm{kDa}$. A putative Type-I polyketide synthase (22244 amino acids) in Volvox carteri was found to be the largest protein in the plant kingdom and was not found in higher plant species. Titin ( $806.46 \mathrm{kDa})$ and misin/midasin $(730.02 \mathrm{kDa})$ were the largest proteins identified in higher plant species. The pl and molecular weight of the plant proteome exhibited a trimodal distribution. An acidic pl (56.44\% of proteins) was found to be predominant over a basic $\mathrm{pl}$ (43.34\% of proteins) and the abundance of acidic pl proteins was higher in unicellular algae species relative to multicellular higher plants. In contrast, the seaweed, Porphyra umbilicalis, possesses a higher proportion of basic pl proteins (70.09\%). Plant proteomes were also found to contain selenocysteine (Sec), amino acid that was found only in lower eukaryotic aquatic plant lineage. Additionally, the plant proteomes also possess ambiguous amino acids Xaa (unknown), Asx (asparagine or aspartic acid), Glx (glutamine or glutamic acid), and Xle (leucine or isoleucine) as well.

\section{Background}

The isoelectric or isoionic point of a protein is the $\mathrm{pH}$ at which a protein carries no net electrical charge and hence is considered neutral [1-4]. The zwitterion form of a protein becomes dominant at neutral $\mathrm{pH}$. The $\mathrm{p}$ / of polypeptides is largely dependent on the dissociation constant of the ionisable groups [5]. The major ionisable groups present in the amino acids are arginine, aspartate, cysteine, histidine, glutamate, lysine, and glutamate, where they play a major role in determining the $p /$ of a protein [6-8]. Co-translational and post-translational modifications of a protein, however, can also play a significant role in determining the $\mathrm{p} /$ of a protein $[9,10]$. The exposure of charged residues to the solvents, hydrogen bonds (diploe interactions) and dehydration also impact the $p /$ of a protein $[11,12]$. The inherent $p /$ of protein, however, is primarily based on its native protein sequence. The $p /$ of a protein is crucial to understanding its biochemical function and thus determining $p /$ is an essential aspect of proteomic studies. During electrophoresis, the direction of movement of a protein in a gel or other matrix depends its'pl, hence numerous proteins can be separated based on their $p /$ [13-16]. Given the impact of post-translational modifications and other biochemical alterations (phosphorylation, methylation, alkylation), however, the predicted $p /$ of a protein will certainly be different than the predicted $p l$; the latter of which is based on the composition of amino acids in a protein $[9,17,18]$. Nonetheless, an estimated isoelectric point is highly important and a commonly identified parameter.

Several studies have been conducted to understand the $p /$ of proteins/polypeptides $[3,19-21]$. These studies have been mainly based on animal, bacteria, and virus models and databases containing the $p /$ of experimentally verified proteins. None of these databases, however, contain more than ten thousand proteins sequences which is very few relative to the availability of proteomic data. Therefore, an analysis was conducted of the $p /$ and molecular weight of proteins from 144 plant species which included 5.87 million protein sequences. This analysis provides an in-depth analysis of the $\mathrm{pland}$ molecular mass of the proteins in the plant kingdom.

\section{Results And Discussion}

\section{Plant proteins range from $0.54 \mathrm{kDa}$ to $2236.8 \mathrm{kDa}$}

A proteome-based analysis of plant proteins of 144 plant species that included more than 5.86 million protein sequences was conducted to determine the molecular mass, pl, and amino acid composition of proteins that exist in plant proteomes (Table 1). The analysis indicated that Hordeum vulgare possessed the highest number (248180) of protein sequences, while Helicosporidium sp. had the lowest number (6033). On average, plant proteomes possess 40988.66 protein sequences per species. The analysis also revealed that the molecular mass of plant proteomes ranged from $0.54 \mathrm{kDa}$ to $2236.8 \mathrm{kDa}$. Volvox carteri was found to possess the largest plant protein (XP_002951836.1) of $2236.8 \mathrm{kDa}$, containing 22244 amino acids ( $p / 5.94)$, while Citrus unshiu possessed the smallest protein of $0.54 \mathrm{kDa}$, containing only four amino acids ( $p / 5.98)$ (id: GAY42954.1). This is the first analysis to document the largest (2236.8 $\mathrm{kDa}$ ) and smallest $(0.54 \mathrm{kDa})$ protein in the plant kingdom. These two proteins have not been functionally annotated and BLASTP analysis in the NCBI database did not identify suitable similarity with any other proteins. A few domains present in the largest protein, however, were found to be conserved with Type-I polyketide synthase. The molecular mass of some other high molecular mass proteins were: 2056.44 kDa (id: XP_001698501.1, type-1 polyketide synthase, pl: 6.00, aa: 21004, Chlamydomonas reinhardtii); 1994.71 kDa (id: XP_001416378.1, polyketide synthase, pl: 7.38, aa: 18193, Ostreococcus lucimarinus); 1932.21 kDa (id: Cz02g22160.t1, unknown protein, pl: 5.7, aa: 18533, Chromochloris zofingiensis); 1814.1 kDa (id: XP_007509537.1, unknown protein, pl: 4.46, aa: 16310, Bathycoccus prasinos); 1649.26 kDa (id: XP_011401890.1, polyketide synthase, pl: 5.53, aa: 16440, Auxenochlorella protothecoides); 1632.35 kDa (id: XP_005650993.1, ketoacyl-synt-domain-containing protein, pl: 5.86, aa: 15797, Coccomyxa subellipsoidea); 1532.91 kDa (id: XP_002507643.1, polyketide synthase, pl: 7.07, aa: 14149, Micromonas commoda); 1370.23 kDa (id: GAX78753.1, hypothetical protein CEUSTIGMA, pl: 5.97, aa: 13200, Chlamydomonas eustigma); 1300.83 kDa (id: XP_022026115.1, unknown protein/filaggrin-like, pl: 11.75, aa: 12581, Helianthus annuus); 1269.42 kDa (id: XP_009350379.1, unknown protein, pl: 5.37, aa: 11880, Pyrus bretschneideri); 1237.34 kDa (id: XP_022840687.1, polyketide synthase, pl: 7.30, aa: 11265, Ostreococcus tauri); 1159.35 kDa (id: XP_005847912.1, polyketide synthase, pl: 5.91, aa: 11464, Chlorella variabilis); 1150.02 kDa (id: PKI66547.1, unknown protein, pl: 3.87, aa: 11234, Punica granatum); 1027.64 kDa (id: Sphfalx0133s0012.1, unknown protein, pl: 4.05, aa: 9126, Sphagnum fallax); 909.93 kDa (id: XP_002985373.1, unknown/titin-like protein, pl: 4.02, aa: 8462, Selaginella moellendorffi); 881.59 kDa (id: KXZ46216.1, hypothetical protein, pl: 5.80, aa: 8881, Gonium pectorale); 848.29 kDa (id: XP_003056330.1, pl: 6.12, aa: 7926, Micromonas pusilla); 813.31 kDa (id: GAQ82263.1, unknown protein, pl: 4.60, aa: 7617, Klebsormidium nitens), 806.46 kDa (id: XP_017639830.1, titin-like, pl: 4.21, aa: 7209, Gossypium arboreum); 806.12 kDa (id: OAE35580.1, pl: 4.83, hypothetical protein, aa: 7651, Marchantia polymorpha); and 802.74 kDa, (id: XP_012444755.1, titin-like, pl: 4.19, aa: 7181, Gossypium raimondii) (Table 1).

On average, approximately $7.38 \%$ of the analysed proteins were found to contain $\geq 100 \mathrm{kDa}$ proteins. The algal species, $V$. carteri, was found to encode largest plant protein (putative polyketide synthase); while other unicellular algae, and multi-cellular lower eukaryotic plants, including bryophytes and pteridophytes, were also found to encode some of the larger proteins (e.g. ketoacyl synthase) in the plant kingdom. The higher eukaryotic plants, including gymnosperms and angiosperms, were not found to encode a high molecular mass polyketide synthase protein. They did, however, possess the high molecular 
mass proteins; titin (806.46 kDa), misin/midasin (730.02 kDa), futsch (622.14 kDa), filaggrin (644.4 kDa), auxin transport protein BIG (568.4 kDa), and von Willebrand factor $(624.74 \mathrm{kDa})$ (Table 1). Titin is an extremely large protein that is greater than $1 \mu \mathrm{M}$ in length and found in human striated muscle [22,23] The largest titin protein found in plants, however, was only $806.46 \mathrm{kDa}$ (Gossypium arboreum). The predicted formula of the $806.46 \mathrm{kDa}$ titin protein was C33863H54610N9232013061S200 and its estimated half-life was 10-30 hours; whereas the predicted formula of the $2236.8 \mathrm{kDa}$ protein of $V$. carteri was C97783H157401N28489030265S637. Almost all of the higher eukaryotic plants were found to possess titin, misin/midasin, and auxin transport protein BIG proteins. Species of unicellular algae were not found to possess titin or misin/midasin proteins. This suggests that titin and misin/midasin proteins originated and evolved in more complex, multicellular organisms rather than unicellular organisms. Thus, the evolution of titin, misin/midasin proteins may also be associated with the evolution of terrestrial plants from aquatic plants.

The presence of the smallest molecular mass protein, other than the tripeptide glutathione (Cys, Gly, and Glu), was also determined. A $0.54 \mathrm{kDa}$ molecular mass protein, containing only four amino acids (MIMF) and starting with methionine and ending with phenylalanine, was identified in Citrus unshiu (id: GAY42954.1) (Table 1). Other low molecular mass plant proteins were 0.57 kDa (NP_001336532.1/ AT5G23115, Arabidopsis thaliana) and 0.63 kDa (AH003201-RA, Amaranthus hypochondriacus). Small proteins found in A. thaliana was MNPKS and that found in A. hypochondriacus was MLPYN, contained only five amino acids. These low molecular mass proteins were not present in all of the studied species and their cellular and molecular functions have not been reported yet. One of the universal small molecular weight plant proteins, however, was identified as cytochrome b6/f complex subunit VIII (chloroplast) (MDIVSLAWAALMVVFTFSLSLVVWGRSGL) that contains only 29 amino acids. Cytochrome b6/f is actively involved in the electron transfer system of photosystem II and regulates photosynthesis [24-28]. It is commonly known that glutathione is the smallest functional polypeptide and that it plays diverse roles in cell signaling [29-31]. The tetra and penta peptides identified in the present analysis, however, were quite different from glutathione and none of them contained Cys, Gly, or Glu amino acids, as found in glutathione. Polypeptides with less than 100 amino acids are considered small proteins and studies indicate that many small proteins are involved in cell metabolism, cell signaling, cell growth, and DNA damage [32-35]. In the era of next-generation sequencing, small protein-coding genes are completely overlooked during genome annotation and get buried amongst an enormous number of open reading frames [36]. Therefore, it is difficult to identify more numbers of small proteins in plants.

A previously conducted comparative study revealed that plant proteins are comparatively smaller than animal proteins, as the former are encoded by fewer exons [37]. Longer proteins harbour more conserved domains and hence display a greater number of biological functions than short proteins. The average protein length of the studied plant species was 424.34 amino acids. A previous study reported the average length of eukaryotic proteins to be 472 amino acids and that the average length of plant proteins is approximately 81 amino acids shorter than animal proteins [37]. Our analysis indicates, however, that plant proteins are approximately 47.66 amino acid shorter than animal proteins. In addition, studies have also indicated that eukaryotic proteins are longer than bacterial proteins and that eukaryote genomes contain approximately 7 fold more proteins (48\% larger) than bacterial genomes [38]. Although the average size of plant proteins was found to be 424.34 amino acids, the average protein size of lower, eukaryotic unicellular aquatic plant species; including Chlamydomonas eustigma, Volvox carteri, Klebsordium nitens, Bathycoccus prasinos, and Durio zibethinus, was found to be $576.56,568.22,538.73,521.05$, and 504.36 amino acids, respectively. This indicates that unicellular plant species have an average protein size that is larger than terrestrial multicellular complex plant species, suggesting that the evolution of plant proteins involved a loss of protein size and hence gene size. The cause of the variability in protein length in the phylogenetic lineage of eukaryotic plants has yet to be elucidated. A multitude of evolutionary factors, including deletion (loss of exons) or fusion of multiple domains of proteins, may have played critical roles in shaping the size of higher plant proteins. Transposon insertion and splitting of genes increases the number of proteins but reduces the average size of the proteins [39-42]. Higher plants contain a very large number of transposable elements and therefore these elements are the most responsible factor to expect to have played a major role in increasing protein numbers and reducing the protein size in higher plants. The percentage of transposable elements in a genome is directly proportional to the genome size of the organism and varies from approximately $3 \%$ in small genomes to approximately $85 \%$ in large genomes [41]. Kirag et al (2007) reported a significant correlation between protein length and the $p /$ of a protein [19]. In our analysis, however, no correlation was found between protein length and the p/ of a protein. For example, titin and misin are two of the larger proteins in plants and they fall in the acidic $p /$ range, but not the alkaline $p /$ range.

\section{Plant encode a higher number of proteins than animals and fungi}

Our analysis identified an average of 40469.47 proteins per genome (Table 1). Previously the number of proteins in plant species was reported as 36795 per genome [37]. On average, animals and fungi encode 25189 and 9113 proteins per genome, respectively [37]. An average of 40469.47 proteins per plant genome is $62.24 \%$ higher than in animals and $444.08 \%$ higher than in fungi. Although, plant species encode a higher number of proteins, their size is smaller than the average size of animal proteins. Notably, green algae contains a smaller number of proteins than higher plants but their average protein size is 1.27 times larger. The average protein size (low to high) in the species of green algae ranged from 273.08 (Helicosporidium sp.) to 576.56 (Chlamydomonas eustigma) amino acids, dicots ranged from 253.34 (Trifolium pratense) to 498.49 (Vitis vinifera), and monocots ranged from 111.54 (Hordeum vulgare) to 473.35 (Brachypodium distachyon) amino acids. The average protein size of monocot proteins (431.07 amino acids), however, is slightly larger than dicots (424.3 amino acids). In addition to transposons, previous studies have reported that endosymbiosis may have also played an important role in the reduction of protein size in plant genomes $[37,43,44]$. This would have been due to the post endosymbiosis acquisition of thousands of genes from the chloroplast, since cyanobacterial proteins are smaller than eukaryotic proteins and cyanobacteria are the ancestors of plastids [37,45]. In this hypothesis, the intermediate size of plant proteins would be the result of the migration of proteins from cyanobacteria (chloroplast) to the plant nucleus, thereby reducing the overall average size of the protein by a dilution effect $[46,47]$.

\section{The pl of plant proteins ranges from 1.99 to 13.96}

Results indicated that the $p /$ of analysed plant proteins ranged from 1.99 (id: PHT45033.1, Capsicum baccatum) to 13.96 (id: PKI59361.1, Punica granatum). The protein with the lowest $p /(1.99)$ was epsin and the protein with the highest $p /(13.96)$ was a hypothetical protein. This is the first study to report on the plant proteins with the lowest and highest $p l$. The $C$. baccatum protein with $p / 1.99$ contains 271 amino acids, whereas the $P$. granatum protein with $p / 13.96$ contains 986 amino acids. The epsin protein $(p / 1.99)$ is composed of 16 amino acid repeats (GWIDGWIDGWIDGW), while the hypothetical protein ( $p / 13.06)$ is 
composed of 64 QKLKSGLT and 31 TRRGLTAV repeats. From among the 20 essential amino acids, the epsin protein only contained five amino acids, namely Asp (68), Gly (68), lle (65), Met (3), and Trp (67). The amino acids were arranged in a repeating manner within the full-length epsin protein. This study is the first to report a full-length protein composed of such a minimum number of essential amino acids. Similarly, the hypothetical protein with the highest $p /$ (13.96) was composed of only nine amino acids, namely Ala (62), Gly (132), Lys (127), Leu (197), Met (M), Pro (4), Gln (64), Arg (132), and Ser (66). Intriguingly, cysteine, which is one of the most important amino acids as it is responsible for the formation of disulphide bonds, was not found in either the smallest or largest protein. Disulphide bonds maintain the conformation and stability of a protein and are typically found in extracellular proteins and only rarely in intracellular proteins [48]. The absence of Cys amino acids in these proteins suggests that these proteins are localized to the intracellular compartments within the cell.

The plant proteome is primarily composed of acidic $p /$ proteins rather than basic $p /$ proteins (Table 1 ). Approximately, $56.44 \%$ of the analysed proteins had a $p /$ within the acidic $p /$ range with an average of pl 5.62 (Table 1). The average percentage of acidic $p /$ proteins was comparatively higher in the lower eukaryotic plants, algae, and bryophytes, than in the higher land plants. A total of $64.18 \%$ of proteins in Chlamydomonas eustigma were found in the acidic p/region, followed by Ostreococcus lucimarinus (64.17\%), Micromonas commoda (63.30\%), Helicosporium sp. (62.97\%), Gonium pectoral (62.76\%), Chromochloris zofingiensis (62.41\%), Coccomyxa subellipsoidea (62.12\%), and Sphagnum fallax (61.83\%). The algal species, Porphyra umbilicalis, had the lowest percentage (29.80\%) of acidic p/proteins. The dicot plant, Punica granatum, and the algal species, Botrycoccus braunii, had a significantly lower percentage of acidic $p /$ proteins $(45.72 \%$ and $47.18 \%$, respectively) relative to other plants. Principal component analysis (PCA) of acidic $p /$ protein content revealed that the acidic proteins of bryophytes and monocots cluster closely to each other compared to algae and eudicot plants (Figure 1). Similarly, in the case of basic $p /$ proteins, a great variation was observed for algae, eudicot and monocot plants (Figure 2). The basic p/proteins of bryophytes, however, were found to be consistent. A previous study reported that protein $\mathrm{p} /$ values are correlated with the sub-cellular localization of the proteins, and that the $p /$ of cytosolic proteins fall below 7 [21]. Among cytosolic proteins are those involved in 26S proteasome degradation, oxidative pentose phosphate pathway, actin/tubulin, mevalonate pathway, sugar and nucleotide biosynthesis, glycolysis, RNA processing, and several other cellular process. Our analysis indicated that the $p /$ of all cytosolic proteins does not fall in the acidic $p /$ range. Ribosomal proteins, pre-mRNA splicing factors, transcription factors, auxin induced protein, extensin, senescence associated protein, cyclin dependent protein kinase and other cytoplasmic proteins had a p/greater than 7 .

In contrast to acidic $p /$ proteins, plants possess a comparatively low number of basic $p /$ proteins. On average, $43.34 \%$ of the analysed plant proteins possessed a $p /$ in the basic range with an average pl of 8.37 (Table 1). The highest percentage of basic $p /$ proteins was found in Porphyra umbilicalis, where $70.09 \%$ of the proteins had a basic $p /$ (Table 1). Punica granatum also had a high percentage (54.11\%) of basic p/proteins (Table 1). The lowest percentage of basic $p /$ proteins was found in the algal species, Chlamydomonas eustigma (35.56\%), followed by Ostreococcus lucimarinus (35.65\%), Micromonas commoda (36.52\%), Helicosporidium sp. (36.89\%), and Gonium pectorale (37.04\%). It is difficult to establish the reason that algal species contain more acidic $p /$ and less basic $p /$ proteins. Porphyra umbilicalis is a cold-water seaweed within the family, Bangiophyceae, and it is the most domesticated marine algae. The $87.7 \mathrm{Mbp}$ haploid genome of $P$. umbilicalis has a $65.8 \% \mathrm{GC}$ content and an evolutionary study reported that the genome of Porphyra umbilicalis had undergone a reduction in size [49]. Since this species is found in the intertidal region of the ocean, it has developed the ability to cope with mid-to-high levels of tidal stress. Porphyra is also tolerant to UV-A and UV-B radiation [49-51]. The high GC content in Porphyra umbilicalis is directly proportional to the high percentage of basic proteins. The GC content of algal species is higher relative to other plant species and algal species possess a lower percentage of basic $p /$ proteins. This suggests that, in algae, percentage GC content is inversely proportional to percentage of proteins with a basic pl. However, this is not true in the case of higher plants.

\section{The pl of plant proteomes exhibits a trimodal distribution}

The $p$ / of the analysed plant proteins ranged from 1.99 to 13.96 and exhibited a trimodal distribution (Figure 3). Schwartz et al., previously reported a trimodal distribution of the $p$ / of eukaryotic proteins[21], however, they did not provide information on the number of sequences/species considered in their study. Proteins are typically soluble near their isoelectric point and the cytoplasm possesses a pH that is close to neutral. This may be the reason for the trimodal distribution of $\mathrm{pl}$. Although the $\mathrm{p} /$ values of proteins estimated in silico or experimentally might be different in vivo, they are typically in close agreement [52]. Kiraga et al., (2006) reported a bimodal distribution of the $p /$ of proteins from all organisms, citing acidic and basic $p /$ as the basis of the modality [19], where modality is defined as the set of data values that appears most often. They reported that taxonomy, ecological niche, proteome size, and sub-cellular localization are correlated with acidic and basic proteins. However, no correlation was observed in the current study between either acidic or basic p/ of proteins with regard to taxonomy, ecological niche, or proteome size. For example, Hordeum vulgare and Brassica napus possess the largest proteomes among the studied plant species, possessing 248180 and 123465 proteins, respectively. In $\mathrm{H}$. vulgare, $53.28 \%$ of the proteins fall in the acidic and $46.50 \%$ fall in the basic $p /$ ranges; while in $B$. napus, $55.28 \%$ of the proteins have an acidic $p /$ and $44.48 \%$ have a basic $p /$. Other species with smaller proteomes, however, possess a higher percentage of acidic or basic proteins (Table 1). Therefore, no correlation exists between the percentage of either acidic or basic proteins and proteome size, taxonomy, or the ecological niche of an organism. Knight et al. also reported a negative correlation between the $p /$ of a protein with phylogeny of the organism [53]. The existence of a trimodal distribution of the $p /$ of the plant proteome can be considered as a virtual 3D-gel of a plant's proteins where the $p /$ of the protein is plotted against the molecular weight of the protein. On average, $0.21 \%$ of the analysed proteins were found to have a neutral $p /(p / 7)$, while only $0.09 \%$ of the proteins in 0 . lucimarinus fall in neutral $\mathrm{pl}$.

\section{Leu is a high-and Trp is a low-abundant amino acid in the plant proteome}

The plant-kingdom-wide proteome analysis revealed that Leu was the most (9.62\%) while Trp was the least (1.28\%) abundant amino acid (Figure 4 , Supplementary File 1). Leu is a nonpolar amino acid, whereas Trp contains an aromatic ring. The distribution of amino acids indicates that the synthesis of nonpolar amino acids is more favoured in the plant proteomes than the polar amino acids or those containing an aromatic ring. The average abundance of other nonpolar amino acids Ala, Gly, Ile, Met, and Val was 6.68\%, 6.80\%, 4.94\%, 2.40\%, and 6.55\%, respectively (Table 2, Supplementary File 1). Trp and Tyr amino acid contain an aromatic ring and the abundance of these two proteins is relatively low in the plant proteome compared to other amino acids. Results of the conducted analysis indicated that the abundance of Ala (17.58\%), Gly (11.76\%), Pro (9.2\%), and Arg (9.81\%) were the highest; whereas, Tyr (1.33\%), Gln 
(2.04\%), Asn (1.53\%), Met (1.45\%), Lys (7.07\%), Lys (2.08\%), lle (1.77\%), Phe (2.01\%), and Glu (3.52\%) were the lowest in Porphyra umbilicalis. In a few algae and seaweeds Ala, Asp, Glu, Gly, Pro, Gln, Arg, Thr, and Val were found in high percentage while Asp, Glu, Phe, His, Ile, Lys, Leu, Met, Asn, Gln, and Ser were found in low percentage (Table 2). These observations indicate that the composition of amino acids in unicellular algae, seaweeds, and gymnosperms are more dynamic and variable than in angiosperms and other terrestrial land plants. Principal component analysis revealed that the low abundant amino acids, Trp, Tyr, His, Met, Cys, and Xaa (unknown), cluster in one group while the high abundant amino acids, Leu, Glu, Ile, Lys, and Ser, cluster in another group (Figure 5). None of the terrestrial land plants were located in the high- and low-abundant amino acid clusters. This suggests that the proteome and amino acid composition of the land plants are more conserved and stable relative to the algae and seaweeds. PCA analysis further revealed that the $p /$ of algae, eudicots, and monocots are lineage specific. The $p /$ of algae, monocots, and eudicots were strongly correlated and clustered together (Figure 5). The question arises, however, as to why the plant proteome contains the highest percentage of Leu and of the lowest percentage of Trp amino acids. Do the energy requirements of the different biosynthetic pathways play a pivotal role in deciding the abundance of amino acids in a proteome? To address this question, an attempt was made to understand the role of amino acid biosynthetic pathways in determining the abundance of specific amino acids in the proteome.

Various amino acids are produced in different biosynthetic pathways [54-58] (Figure 6). In some cases, a few amino acids act as the substrate for the biosynthesis of other amino acids; whereas in other cases, allosteric inhibition of the biosynthesis of amino acids occurs [59-61]. In all of these biosynthetic pathways, ATP or NADH/NADPH are used as a source of energy, along with substrate that play a vital role in the biosynthesis of amino acids. Overall, the biosynthesis of 20 essential amino acid families are grouped by metabolic precursors [62] (Table 3); namely a-ketoglutarate (Arg, Gln, Glu, Pro), pyruvate (Ala, Ile, Leu, Val), 3-phosphoglycerate (Cys, Gly, Ser), phosphoenolpyruvate and erythrose 4-phosphate (Phe, Trp, Tyr), oxaloacetate (Asn, Asp, Lys, Met, Thr), and ribose 5-phosphate (His) (Table 3) [62]. Ala, Ile, Leu, and Val are synthesized from pyruvate; Arg, Glu, Gln, and Pro are synthesized from a-ketoglutarate and Gly and Ser are synthesized from 3-phosphoglycerate[62]; all of which have a higher abundance in the plant proteome relative to the other amino acids (Figure 6, Table 3). 3-phosphoglycerate and pyruvate are intermediates of glycolysis and the amino acids synthesized from these intermediates maintain a high abundance in the plant proteome. The intermediate, 3-phosphoglycerate, is formed in an early step of glycolysis[62]. The amino acids Gly and Ser are synthesized from 3-phosphoglycerate and are also found abundantly in the plant proteome (Figure 6, Table 3). The amino acid Cys, which is also synthesized from 3-phosphoglycerate[62], however, is present in low abundance (1.85\%) in the plant proteome. The low abundance of Cys may be due to the allosteric inhibition. Phe (3.97), Trp (1.28\%), and Try (2.67\%) contain an aromatic ring and are synthesized via phosphoenolpyruvate and erythrose 4-phospahte. The aromatic amino acids are in low abundance in the plant proteome (Table). Since Phe also plays a role in the biosynthesis of Tyr, the abundance of Phe is relatively higher than Trp and Tyr. Glucose 6-phosphate gives rise to ribose 5-phosphate in a complex reaction of four steps[62] and His gets subsequently synthesized from ribose 5-phosphate. It is possible that the complexity of the biosynthetic pathways of amino acids containing ring compounds might be the reason for their low abundance in the plant proteome.

\section{Plants possess selenocysteine (Sec) and other novel amino acids}

A few of the plant proteomes that were analysed had proteins containing the amino acid, selenocysteine (Sec). C. reinhardtii, M. pusilla, and $V$. carteri contained 9, 16, and $11 \mathrm{Sec}$ amino acids in their proteome, respectively. Selenium containing selenoproteins are commonly found in animals but have been reported to be present in plant species. Novoselov et al., (2002) reported the presence of a selenoprotein in $C$. reinhardtii [63]. In our analysis, nine selenoproteins (selenoprotein $\mathrm{H}$, selenoprotein $\mathrm{K} 1$, selenoprotein $\mathrm{M} 2$, selenoprotein $\mathrm{T}$, selenoprotein $\mathrm{U}$, selenoprotein W1, selenoprotein W2, NADPH-dependent thioredoxin reductase 1 , and glutathione peroxidase) were identified in $C$. reinhardtii. In addition, $M$. pusilla was found to possess 14 Sec-containing proteins [DSBA oxidoreductase (2 no.), selenoprotein T, glutathione peroxidase (4 no.), selenoprotein W, selenoprotein, selenoprotein $\mathrm{M}$, selenoprotein $\mathrm{H}$, selenoprotein $\mathrm{O}$, methyltransferase, and peroxiredoxin). In addition, $\mathrm{V}$. carteri was found to possess $10 \mathrm{Sec}$ containing proteins (selenoprotein $\mathrm{T}$, selenoprotein $\mathrm{K} 1$, selenoprotein $\mathrm{H}$, selenoprotein $\mathrm{W} 1$, selenoprotein $\mathrm{M} 2$, selenoprotein $\mathrm{U}$, glutathione peroxidase, membrane selenoprotein, NADPH-dependent thioredoxin reductase, and peptide methionine-S-sulfoxide reductase). To the best of our knowledge, this is the first report of selenoproteins in $M$. pusilla and $V$. carteri and the first to report of $\mathrm{H}, \mathrm{K} 1, \mathrm{~T}, \mathrm{U}, \mathrm{M}, \mathrm{M} 2, \mathrm{O}, \mathrm{W} 1$, and W2 selenoprotein families collectively in C. reinhardtii, M. pusilla, and $V$. carteri. The I, N, P, R, S, and V selenoprotein family members are commonly found in the animal kingdom[64] but are absent in $C$. reinhardtii, M. pusilla, and $V$. carteri. This is also the first report of the Sec-containing proteins, DSBA oxidoreductase, methyltransferase, peroxiredoxin, peptide methionine-S-sulfoxide reductase, and membrane selenoprotein in plants lineage (algae). Notably, the selenoproteins DSBA oxidoreductase, methyltransferase, peroxiredoxin, peptide methionine-S-sulfoxide reductase, and membrane selenoprotein have not been reported in animal species. Outside of algal species, no other plant species; including bryophytes, pteridophytes gymnosperms and angiosperms, were found to possess a selenoprotein.

Some plant proteomes were also found to possess a few unknown or unspecified amino acids, commonly designated as Xaa (X). Among the analysed plant species, Aegilops tauschii, Amaranthus hypochondriacus, and Amborella trichocarpa encoded 149377, 55412, and 25843 X amino acids, respectively. Solanum lycopersicum was found to contain only one $\mathrm{X}$ amino acid, while at least 18 species (Solanum pennellii, Solanum tuberosum, Sorghum bicolor, Sphagnum fallax, Spinacia oleracea, Spirodela polyrhiza, Tarenaya hassleriana, Theobroma cacao, Trifolium pratense, Trifolium subterraneum, Triticum aestivum, Triticum urartu, Vigna angularis, Vigna radiata, Vigna anguiculata, Vitis vinifera, Volvox carteri, and Zostera marina) were found to lack any Xaa amino acids in their proteome. Xaa amino acids are known as non-protein amino acids as they have not been associated with any specific codons. Among the studied plant species, ten were found to contain amino acid B (Asx) that codes for the ambiguous amino acid Asn or Asp that is translated as Asp. Species that were found to possess an Asx amino acid included Arachis duranensis (1), Brachypodium stacei (40), Dichanthelium oligosanthes (20), Dunaliella salina (31), Glycine max (1), Malus domestica (4080), Momordica charantia (98), Nelumbo nucifera (64), Prunus persica (1), and Trifolium pratense (76). At least six species were found to possess a J (Xle) amino acid. Xle amino acid can encode either Leu or lle but during translation produces Leu. Species that were found to possess Xle amino acids included Arabidopsis thaliana (10), Dichanthelium oligosanthes (11), Malus domestica (2175), Momordica charantia (39), Nelumbo nucifera (29), and Trifolium pratense (39). At least seven species were found to possess a Z (Glx) amino acid that codes for either Glu or GIn, which is subsequently translated as Glu. Species that were found to encode a Glx amino acid included Brachypodium stacei (20), Dichanthelium oligosanthes (16), Dunaliella salina (7), Malus domestica (1552), Momordica charantia (28), Nelumbo nucifera (14), and Trifolium pratense (25). Among the studied species, Malus domestica was found to contain highest number of ambiguous amino acids (Asx, Xle, and Glx). Bodley and Davie (1966) reported the incorporation of

Page 5/21 
ambiguous amino acids in a peptide chain [65]. The presence of ethanol or streptomycin or a high magnesium ion concentration induces ambiguous coding in the peptide chain [65]. They reported that poly-U (uridylic acid) in the presence of a high concentration of magnesium ions or ethanol or streptomycin induces the incorporation of Leu/lle amino acids in a peptide chain [65]. This explains how the specificity of the protein translation process can be altered by the presence of environmental factors. A high concentration of magnesium ions, organic solvents, antibiotics, $\mathrm{pH}$, and low temperature have the ability to modify the coding specificity of a peptide chain [65]. Under some conditions poly-U triggers the incorporation of Leu and Ile or Phe [65]. Malus domestica is rich in magnesium ions (1\%) and this might explain the presence of such a high number of ambiguous amino acids in its proteome.

\section{Conclusion}

A proteomic analysis of the plant kingdom identified proteins with a great range of molecular mass and isoelectric points. Isoelectric points ranged from 1.99 to 13.96 , covering almost the entire $\mathrm{pH}$ range. It is quite intriguing to think about the functions of protein at $p / 1.99$ or 13.96 . Proteins with an acidic $p /$ predominate over the proteins with an alkaline $p l$, and the presence of proteins with a $p /$ that is near neutral is very negligible. The percentage of proteins with acidic or basic $p / s$ is not related to the host cell, alkalinity or acidity of the environment. Additionally, the GC content of a genome or size distribution of the overall proteome are not directly proportional to the distribution (percent basic vs. percent acidic) of the p/ in the proteome. The presence of Sec-containing proteins in some plant species needs to be further investigated to determine their functional role. Similarly, the presence of ambiguous amino acids in plant species should be further evaluated individually to understand whether these ambiguous amino acids are encoded by any specific codon in mRNA. A major question arises from this study is, whether the incorporation of ambiguous amino acids in the peptide chain of the protein brings any impact at the gene/genome level and incorporate the respective codon for the ambiguous amino acid and regulated genomic rearrangement through reverse central dogma approach. The presence of a pyrrolysine amino acid in the plant kingdom was not observed in the present study.

\section{Methods}

Protein sequences of the entire proteome of the analysed plant species were downloaded from the National Center for Biotechnology Information (NCBI) and Phytozome, DOE Joint Genome Institute (https://phytozome.jgi.doe.gov/pz/portal.html). All of the studied sequences were annotated nuclear-encoded proteins. The isoelectric point of each protein of each of the analysed plant species was calculated individually using the Python-based command line "Protein isoelectric point calculator" (IPC Python) in a Linux platform [2]. The source code used was as written by Kozlowski (2016).

Once the molecular mass and isoelectric point of the proteins in each species was determined, they were separated into acidic and basic $p /$ categories. Subsequently, the average $p /$ and percentage of proteins in each category was calculated using a Microsoft excel worksheet. A graph comparison of isoelectric point versus molecular mass was prepared using a python-based platform. Pearson-correlation $(r=0.19, p=0)$ was used for the association analysis of molecular mass and isoelectric point. The X-axis data statistics were as follows: mean, $4.717365 \mathrm{e}+01$; std, 3.662983e+01; min, 8.909000e-02; $25 \%$, $2.279452 \mathrm{e}+01 ; 50 \%, 3.874486 \mathrm{e}+01 ; 75 \%, 5.999628 \mathrm{e}+01$, and max, $2.236803 \mathrm{e}+03$. The Y-axis data statistics were: mean, $6.840657 \mathrm{e}+00 ;$ std, $1.594912 \mathrm{e}+00$; $\min , 1.990000 \mathrm{e}+00 ; 25 \%, 5.537000 \mathrm{e}+00 ; 50 \%, 6.605000 \mathrm{e}+00 ; 75 \%, 8.053000 \mathrm{e}+00$, and $\max , 1.396300 \mathrm{e}+01$.

\section{Principal component analysis}

Principal component analysis of the plant proteome parameters was carried out using a portable Unscrambler software version 9.7 using the excel file format. For acidic and basic $p l$, the plant proteome data were grouped according to the plant lineage algae, bryophyte, monocot, and eudicot plants. The average of acidic and basic $p /$ was used to construct the PCA plot. Similarly, amino acid abundance was also analysed in relation to algae, bryophyte, eudicot, and monocot lineage.

\section{List Of Abbreviations}

PPCD VHS3-like: phosphopantothenoylcysteine decarboxylase subunit VHS3-like isoform X2, 60S RP L41: 60S ribosomal protein subunit L41, DDHGT 4A: Dolichyl-diphosphooligosaccharideprotein glycosyltransferase subunit 4A, PERK2: proline-rich receptor-like protein kinase PERK2, RNA Pol. II Med 17: mediator of RNA polymerase II subunit 17, FS CAYBR BP: fibrous sheath CABYR-binding protein-like, PKS: polyketide synthase, PS-I RC N: photosystem I reaction center subunit N, chloroplastic, partial; RPB1: DNA-directed RNA polymerase Il subunit RPB1-like isoform X3, GRCW protein: glycine-rich cell wall structural protein, SR45: serine/arginine-rich splicing factor SR45-like, IMP:inosine-5'-monophosphate cyclohydrolase, ZRF: zinc ring finger-type, CWP:cell wall protein, DDGT: dolichyl-diphosphooligosaccharideprotein glycosyltransferase subunit 4A, PKDP: polycystic kidney disease protein 1-like 3, CSF: cleavage stimulation factor subunit 2 tau variant-like, AAPT: aminoalcoholphosphotransferase, RBP: RNA binding protein, SARMP: serine/arginine repetitive matrix protein 2-like, ER TF: ethylene responsive transcription factor, CDPK: cyclin-dependent serine/threonine-protein kinase, LEA: late embryogenesis associated protein, DDG: dolichyldiphosphooligosaccharideprotein glycosyltransferase subunit 4A, NFD: nuclear fusion defective, SVC: satellite virus coat protein, PPCD: phosphopantothenoylcysteine decarboxylase, SCP: spore coat protein, ATF7IP: activating transcription factor 7-interacting protein 1.

\section{Declarations}

\section{Ethics approval and consent to participate}

Not applicable

\section{Consent for publication}

All authors agree and have consent for publication 
Availability of data material

All the studied data were taken from publicly available databases and data associated with the manuscript is provided in supplementary file.

\section{Competing of interest}

There is no competing of interest to declare

Funding

Not available

Authors contribution

TKM: conceived the idea, collected the protein sequences, analysed and interpreted the data, drafted the manuscript, ALK: revised the manuscript, AH: drafted and revised the manuscript, EFA: drafted and revised the manuscript, AAH: revised the manuscript.

\section{Acknowledgement}

Not available

\section{References}

1. Kirkwood J, Hargreaves D, O'Keefe S, Wilson J. Using isoelectric point to determine the $\mathrm{pH}$ for initial protein crystallization trials. Bioinformatics [Internet]. 2015;31:1444-51. Available from: http://dx.doi.org/10.1093/bioinformatics/btv011

2. Kozlowski LP. IPC - Isoelectric Point Calculator. Biol Direct [Internet]. 2016;11:55. Available from: https://doi.org/10.1186/s13062-016-0159-9

3. Kozlowski LP. Proteome-pl: proteome isoelectric point database. Nucleic Acids Res [Internet]. 2016/10/26. Oxford University Press; 2017;45:D1112-6. Available from: https://www.ncbi.nlm.nih.gov/pubmed/27789699

4. Stekhoven F, Gorissen M, Flik G. The isoelectric point, a key to understanding a variety of biochemical problems: a minireview. Fish Physiol Biochem [Internet]. 2008;34:1-8. Available from: https://doi.org/10.1007/s10695-007-9145-6

5. Kenneth W, Kenneth G, Raymond E. General Chemistry. 4th ed. Saunders College Publishing; 1992.

6. Pace CN, Grimsley GR, Scholtz JM. Protein ionizable groups: pK values and their contribution to protein stability and solubility. J Biol Chem. 2009;284:13285-9.

7. Grimsley GR, Scholtz JM, Pace CN. A summary of the measured pK values of the ionizable groups in folded proteins. Protein Sci [Internet]. $2008 / 12 / 02$. Wiley Subscription Services, Inc., A Wiley Company; 2009;18:247-51. Available from: https://www.ncbi.nlm.nih.gov/pubmed/19177368

8. Masunov A, Lazaridis T. Potentials of Mean Force between Ionizable Amino Acid Side Chains in Water. J Am Chem Soc [Internet]. American Chemical Society; 2003;125:1722-30. Available from: https://doi.org/10.1021/ja025521w

9. Zhu K, Zhao J, Lubman DM, Miller FR, Barder TJ. Protein pl Shifts due to Posttranslational Modifications in the Separation and Characterization of Proteins. Anal Chem [Internet]. American Chemical Society; 2005;77:2745-55. Available from: https://doi.org/10.1021/ac048494w

10. Locke D, Koreen I V, Harris AL. Isoelectric points and post-translational modifications of connexin26 and connexin32. FASEB J [Internet]. Federation of American Societies for Experimental Biology; 2006;20:1221-3. Available from: https://doi.org/10.1096/fj.05-5309fje

11. Youden WJ, Denny FE. Factors Influencing the pH Equilibrium Known as the Isoelectric Point of Plant Tissue. Am J Bot [Internet]. Botanical Society of America; 1926;13:743-53. Available from: http://www.jstor.org/stable/2435477

12. Shaw KL, Grimsley GR, Yakovlev GI, Makarov AA, Pace CN. The effect of net charge on the solubility, activity, and stability of ribonuclease Sa. Protein Sci [Internet]. Cold Spring Harbor Laboratory Press; 2001;10:1206-15. Available from: http://www.ncbi.nlm.nih.gov/pmc/articles/PMC2374010/

13. Saraswathy N, Ramalingam P. Introduction to proteomics. In: Saraswathy N, Ramalingam PBT-C and T in G and P, editors. Woodhead Publ Ser Biomed [Internet]. Woodhead Publishing; 2011. p. 147-58. Available from: http://www.sciencedirect.com/science/article/pii/B9781907568107500109

14. Gygi SP, Corthals GL, Zhang Y, Rochon Y, Aebersold R. Evaluation of two-dimensional gel electrophoresis-based proteome analysis technology. Proc Natl Acad Sci [Internet]. 2000;97:9390 LP-9395. Available from: http://www.pnas.org/content/97/17/9390.abstract

15. Rabilloud T, Lelong C. Two-dimensional gel electrophoresis in proteomics: A tutorial. J Proteomics [Internet]. 2011;74:1829-41. Available from: http://www.sciencedirect.com/science/article/pii/S1874391911002545

16. Kumar M, Singh R, Meena A, Patidar BS, Prasad R, Chhabra SK, et al. An Improved 2-Dimensional Gel Electrophoresis Method for Resolving Human Erythrocyte Membrane Proteins. Proteomics Insights [Internet]. SAGE Publications Ltd STM; 2017;8:1178641817700880. Available from:

Page $7 / 21$ 
https://doi.org/10.1177/1178641817700880

17. Anderson JC, Peck SC. A simple and rapid technique for detecting protein phosphorylation using one-dimensional isoelectric focusing gels and immunoblot analysis. Plant J. 2008;55:881-5.

18. Jones LR, Simmerman HK, Wilson WW, Gurd FR, Wegener AD. Purification and characterization of phospholamban from canine cardiac sarcoplasmic reticulum. J Biol Chem [Internet]. 1985;260:7721-30. Available from: http://www.jbc.org/content/260/12/7721.abstract

19. Kiraga J, Mackiewicz P, Mackiewicz D, Kowalczuk M, Biecek P, Polak N, et al. The relationships between the isoelectric point and: length of proteins, taxonomy and ecology of organisms. BMC Genomics [Internet]. BioMed Central; 2007;8:163. Available from:

https://www.ncbi.nlm.nih.gov/pubmed/17565672

20. Carugo O. Isoelectric points of multi-domain proteins. Bioinformation. 2007;2:101-4.

21. Schwartz R, Ting CS, King J. Whole proteome pl values correlate with subcellular localizations of proteins for organisms within the three domains of life. Genome Res. 2001;11:703-9.

22. Labeit S, Barlow DP, Gautel M, Gibson T, Holt J, Hsieh C-L, et al. A regular pattern of two types of 100-residue motif in the sequence of titin. Nature [Internet]. Nature Publishing Group; 1990;345:273. Available from: http://dx.doi.org/10.1038/345273a0

23. Kurzban GP, Wang K. Giant polypeptides of skeletal muscle titin: Sedimentation equilibrium in guanidine hydrochloride. Biochem Biophys Res Commun [Internet]. 1988;150:1155-61. Available from: http://www.sciencedirect.com/science/article/pii/0006291X88907504

24. Kurisu G, Zhang H, Smith JL, Cramer WA. Structure of the Cytochrome b6f Complex of Oxygenic Photosynthesis: Tuning the Cavity. Science (80- ) [Internet]. 2003;302:1009 LP-1014. Available from: http://science.sciencemag.org/content/302/5647/1009.abstract

25. Leister D, Schneider ABT-. From Genes to Photosynthesis in Arabidopsis thaliana. Int Rev Cytol [Internet]. Academic Press; 2003;228:31-83. Available from: http://www.sciencedirect.com/science/article/pii/S0074769603280025

26. Barbagallo RP, Finazzi G, Forti G. Effects of Inhibitors on the Activity of the Cytochrome b6f Complex: Evidence for the Existence of Two Binding Pockets in the Lumenal Site. Biochemistry [Internet]. American Chemical Society; 1999;38:12814-21. Available from: https://doi.org/10.1021/bi990424+

27. Cramer WA, Soriano GM, Ponomarev M, Huang D, Zhang H, Martinez SE, et al. Some New Structural Aspects And Old Controversies Concerning The Cytochrome B6f Complex Of Oxygenic Photosynthesis. Annu Rev Plant Physiol Plant Mol Biol [Internet]. Annual Reviews; 1996;47:477-508. Available from: https://doi.org/10.1146/annurev.arplant.47.1.477

28. Kallas T. The Cytochrome b6f Complex. In: Bryant DA, editor. Mol Biol Cyanobacteria [Internet]. Dordrecht: Springer Netherlands; 1994. p. $259-317$. Available from: https://doi.org/10.1007/978-94-011-0227-8_9

29. Filomeni G, Rotilio G, Ciriolo MR. Cell signalling and the glutathione redox system. Biochem Pharmacol [Internet]. 2002;64:1057-64. Available from: http://www.sciencedirect.com/science/article/pii/S0006295202011760

30. Zhang H, Forman HJ. Glutathione synthesis and its role in redox signaling. Semin Cell Dev Biol [Internet]. 2012/04/03. 2012;23:722-8. Available from: https://www.ncbi.nlm.nih.gov/pubmed/22504020

31. Aquilano K, Baldelli S, Ciriolo MR. Glutathione: new roles in redox signaling for an old antioxidant. Front Pharmacol [Internet]. 2014;5:196. Available from: https://www.frontiersin.org/article/10.3389/fphar.2014.00196

32. Su M, Ling Y, Yu J, Wu J, Xiao J. Small proteins: untapped area of potential biological importance. Front Genet [Internet]. Frontiers Media S.A.; $2013 ; 4: 286$. Available from: https://www.ncbi.nlm.nih.gov/pubmed/24379829

33. Setlow P. I will survive: DNA protection in bacterial spores. Trends Microbiol [Internet]. Elsevier; 2007;15:172-80. Available from: https://doi.org/10.1016/j.tim.2007.02.004

34. Schalk C, Cognat V, Graindorge S, Vincent T, Voinnet O, Molinier J. Small RNA-mediated repair of UV-induced DNA lesions by the DNA DAMAGE-BINDING PROTEIN 2 and ARGONAUTE 1. Proc Natl Acad Sci U S A [Internet]. 2017/03/21. National Academy of Sciences; 2017;114:E2965-74. Available from: https://www.ncbi.nlm.nih.gov/pubmed/28325872

35. Xue Y, Shen L, Cui Y, Zhang H, Chen Q, Cui A, et al. Tff3, as a Novel Peptide, Regulates Hepatic Glucose Metabolism. PLoS One [Internet]. Public Library of Science; 2013;8:e75240. Available from: https://doi.org/10.1371/journal.pone.0075240

36. Basrai M a, Hieter P, Boeke JD. Small Open Reading Frames: Beautiful Needles in the Haystack Small Open Reading Frames: Beautiful Needles in the Haystack. Genome Res. 1997;7:768-71.

37. Ramírez-Sánchez O, Pérez-Rodríguez P, Delaye L, Tiessen A. Plant Proteins Are Smaller Because They Are Encoded by Fewer Exons than Animal Proteins. Genomics Proteomics Bioinformatics [Internet]. 2016/12/18. Elsevier; 2016;14:357-70. Available from: https://www.ncbi.nlm.nih.gov/pubmed/27998811 
38. Tiessen A, Pérez-Rodríguez P, Delaye-Arredondo LJ. Mathematical modeling and comparison of protein size distribution in different plant, animal, fungal and microbial species reveals a negative correlation between protein size and protein number, thus providing insight into the evolution of proteomes. BMC Res Notes [Internet]. BioMed Central; 2012;5:85. Available from: https://www.ncbi.nlm.nih.gov/pubmed/22296664

39. Purugganan M, Wessler S. The splicing of transposable elements and its role in intron evolution. Genetica. 1992;86:295-303.

40. Huff JT, Zilberman D, Roy SW. Mechanism for DNA transposons to generate introns on genomic scales. Nature [Internet]. 2016/10/19. 2016;538:533-6. Available from: https://www.ncbi.nlm.nih.gov/pubmed/27760113

41. Lee S-I, Kim N-S. Transposable elements and genome size variations in plants. Genomics Inform [Internet]. 2014/09/30. Korea Genome Organization; 2014;12:87-97. Available from: https://www.ncbi.nlm.nih.gov/pubmed/25317107

42. Plasterk RHA. Transposable Elements [Internet]. Brenner S, Miller JHBT-E of G, editors. Encycl. Genet. New York: Academic Press; 2001. Available from: http://www.sciencedirect.com/science/article/pii/B0122270800013161

43. Martin W, Rujan T, Richly E, Hansen A, Cornelsen S, Lins T, et al. Evolutionary analysis of Arabidopsis, cyanobacterial, and chloroplast genomes reveals plastid phylogeny and thousands of cyanobacterial genes in the nucleus. Proc Natl Acad Sci U S A [Internet]. National Academy of Sciences; 2002;99:1224651. Available from: http://www.ncbi.nlm.nih.gov/pmc/articles/PMC129430/

44. Sloan DB, Moran NA. Genome Reduction and Co-evolution between the Primary and Secondary Bacterial Symbionts of Psyllids. Mol Biol Evol [Internet]. 2012;29:3781-92. Available from: http://dx.doi.org/10.1093/molbev/mss180

45. Mohanta TK, Pudake RN, Bae H. Genome-wide identification of major protein families of cyanobacteria and genomic insight into the circadian rhythm. Eur J Phycol. 2017;52.

46. Reyes-Prieto A, Weber APM, Bhattacharya D. The Origin and Establishment of the Plastid in Algae and Plants. Annu Rev Genet [Internet]. Annual Reviews; 2007;41:147-68. Available from: https://doi.org/10.1146/annurev.genet.41.110306.130134

47. Martin W, Stoebe B, Goremykin V, Hansmann S, Hasegawa M, Kowallik K V. Gene transfer to the nucleus and the evolution of chloroplasts. Nature [Internet]. Macmillan Magazines Ltd.; 1998;393:162. Available from: http://dx.doi.org/10.1038/30234

48. Mallick P, Boutz DR, Eisenberg D, Yeates TO. Genomic evidence that the intracellular proteins of archaeal microbes contain disulfide bonds. Proc Natl Acad Sci U S A [Internet]. 2002/07/09. The National Academy of Sciences; 2002;99:9679-84. Available from: https://www.ncbi.nlm.nih.gov/pubmed/12107280

49. Brawley SH, Blouin NA, Ficko-Blean E, Wheeler GL, Lohr M, Goodson H V, et al. Insights into the red algae and eukaryotic evolution from the genome of Porphyra umbilicalis (Bangiophyceae, Rhodophyta). Proc Natl Acad Sci [Internet]. 2017;114:E6361 LP-E6370. Available from:

http://www.pnas.org/content/114/31/E6361.abstract

50. Dring MJ, Wagner A, Boeskov J, Lüning K. Sensitivity of intertidal and subtidal red algae to UVA and UVB radiation, as monitored by Chlorophyll fluorescence measurements: Influence of collection depth and season, and length of irradiation. Eur J Phycol [Internet]. Taylor \& Francis; 1996;31:293-302. Available from: https://doi.org/10.1080/09670269600651511

51. Gröniger A, Hallier C, Häder DP. Influence of UV radiation and visible light on Porphyra umbilicalis: Photoinhibition and MAA concentration. J Appl Phycol [Internet]. 1999;11:437. Available from: https://doi.org/10.1023/A:1008179322198

52. Sillero A, Ribeiro JM. Isoelectric points of proteins: Theoretical determination. Anal Biochem [Internet]. 1989;179:319-25. Available from: http://www.sciencedirect.com/science/article/pii/000326978990136X

53. Knight CG, Kassen R, Hebestreit H, Rainey PB. Global analysis of predicted proteomes: functional adaptation of physical properties. Proc Natl Acad Sci U S A [Internet]. 2004/05/18. National Academy of Sciences; 2004;101:8390-5. Available from: https://www.ncbi.nlm.nih.gov/pubmed/15150418

54. Gibson F, Pittard J. Pathways of biosynthesis of aromatic amino acids and vitamins and their control in microorganisms. Bacteriol Rev [Internet]. 1968;32:465-92. Available from: https://www.ncbi.nlm.nih.gov/pubmed/4884716

55. Tzin V, Galili G. New Insights into the Shikimate and Aromatic Amino Acids Biosynthesis Pathways in Plants. Mol Plant [Internet]. 2010;3:956-72. Available from: http://www.sciencedirect.com/science/article/pii/S1674205214605475

56. Szabados L, Savouré A. Proline: a multifunctional amino acid. Trends Plant Sci [Internet]. 2010;15:89-97. Available from:

http://www.sciencedirect.com/science/article/pii/S1360138509002982

57. Galili G, Höfgen R. Metabolic Engineering of Amino Acids and Storage Proteins in Plants. Metab Eng [Internet]. 2002;4:3-11. Available from: http://www.sciencedirect.com/science/article/pii/S1096717601902034

58. Yoshida S. Biosynthesis and Conversion of Aromatic Amino Acids in Plants. Annu Rev Plant Physiol [Internet]. Annual Reviews; 1969;20:41-62. Available from: https://doi.org/10.1146/annurev.pp.20.060169.000353

Page $9 / 21$ 
59. Light SH, Anderson WF. The diversity of allosteric controls at the gateway to aromatic amino acid biosynthesis. Protein Sci [Internet]. 2013/02/11. Wiley Subscription Services, Inc., A Wiley Company; 2013;22:395-404. Available from: https://www.ncbi.nlm.nih.gov/pubmed/23400945

60. Berg J, Tymoczko J, Stryer L. Amino Acid Biosynthesis Is Regulated by Feedback Inhibition. Biochemistry. 5th ed. New York: WH Freeman; 2002.

61. Nelson D, Cox M. Amino acid biosynthesis is under allosteric regulation. In: Lehninger AL, editor. Lehlingers Princ Biochem. 4th ed. 2005. p. 833-80.

62. Nelson D, Cox M. Biosynthesis of amino acids, nucleotides, and related molecules. Lehlinger Princ Biochem. 4th ed. New York: W.H. Freeman and Company; 2005. p. 842.

63. Novoselov S V, Rao M, Onoshko N V, Zhi H, Kryukov G V, Xiang Y, et al. Selenoproteins and selenocysteine insertion system in the model plant cell system, Chlamydomonas reinhardtii. EMBO J [Internet]. Oxford University Press; 2002;21:3681-93. Available from: https://www.ncbi.nlm.nih.gov/pubmed/12110581

64. Reeves MA, Hoffmann PR. The human selenoproteome: recent insights into functions and regulation. Cell Mol Life Sci [Internet]. 2009;66:2457-78. Available from: https://doi.org/10.1007/s00018-009-0032-4

65. Bodley JW, Davie EW. A study of the mechanism of ambiguous amino acid coding by poly U: the nature of the products. J Mol Biol [Internet]. 1966;18:344-55. Available from: http://www.sciencedirect.com/science/article/pii/S0022283666802528

\section{Tables}

Table 1

Details of plant proteome. Table shows acidic pI of proteins predominates the basic pI. However, in sea weed Porphyra umbilicalis, basic $p I$ predominates over the acidic $p I$. Putative polyketide synthase type I found in lower eukaryote Volvox carteri was found to be the largest protein in the plant lineage. However, titin was found to be the largest protein in the higher eukaryotic land plants. Asterisks represents no specific data available for the said item. 


\begin{tabular}{|c|c|c|c|c|c|c|c|c|c|c|c|c|c|c|}
\hline $\begin{array}{l}\text { Name of the } \\
\text { species }\end{array}$ & $\begin{array}{l}\text { Total No. } \\
\text { Of Protein } \\
\text { Sequences } \\
\text { Studied }\end{array}$ & $\begin{array}{l}\text { Highest } \\
\text { Mol. } \\
\text { Wt. } \\
(\mathrm{kDa}) \\
\text { of } \\
\text { Protein }\end{array}$ & $\begin{array}{l}\text { Name of } \\
\text { the } \\
\text { Protein } \\
\text { with } \\
\text { Highest } \\
\text { Mol. Wt. }\end{array}$ & $\begin{array}{l}\text { Lowest } \\
\text { Mol. } \\
\text { Wt. } \\
(\mathrm{kDa}) \\
\text { of } \\
\text { Protein }\end{array}$ & $\begin{array}{l}\text { Name of the } \\
\text { Protein with } \\
\text { lowest Mol. Wt. }\end{array}$ & $\begin{array}{l}\text { Highest } \\
p I \text { of } \\
\text { Protein }\end{array}$ & $\begin{array}{l}\text { Name of the } \\
\text { Protein with } \\
\text { highest } p I\end{array}$ & $\begin{array}{l}\text { Lowest } \\
\text { pI of } \\
\text { Protein }\end{array}$ & $\begin{array}{l}\text { Name of the } \\
\text { Protein with } \\
\text { lowest } p I\end{array}$ & $\begin{array}{l}\text { No. Of } \\
\text { Proteins } \\
\text { in } \\
\text { Acidic } \\
p I\end{array}$ & $\begin{array}{l}\text { No. Of } \\
\text { Proteins } \\
\text { in Basic } \\
p I\end{array}$ & $\begin{array}{c}\text { No. Of } \\
\text { Proteins } \\
\text { in } \\
\text { Neutral } \\
p I\end{array}$ & $\begin{array}{l}\text { Average } \\
\text { of } \\
\text { Acidic } \\
p I\end{array}$ & $\begin{array}{l}\text { Av } \\
\text { of } \\
p I\end{array}$ \\
\hline Aegilops tauschii & 55713 & 605.202 & Misin & 3.169 & Cyt b6/f VIII & 13.159 & SARMP 2-like & 2.409 & Nucleolin-like & 30488 & 25116 & 109 & 5.64 & 8.7 \\
\hline $\begin{array}{l}\text { Amaranthus } \\
\text { hypochondriacus }\end{array}$ & 23879 & 596.11 & Unknown & 0.63 & Unknown & 12.67 & Unknown & 2.498 & Unknown & 13009 & 10833 & 37 & 5.58 & 8. \\
\hline $\begin{array}{l}\text { Amborella } \\
\text { trichopoda }\end{array}$ & 27313 & 554.72 & Unknown & 4.32 & Unknown & 12.93 & Unknown & 2.587 & Unknown & 14583 & 12677 & 53 & 5.53 & 8.5 \\
\hline $\begin{array}{l}\text { Anacardium } \\
\text { occidentale }\end{array}$ & 82170 & 457.50 & Unknown & 3.10 & Unknown & 12.61 & Unknown & 2.58 & Unknown & 46898 & 35100 & 172 & 5.65 & 8.2 \\
\hline Ananas comosus & 35775 & 605.85 & Midasin & 3.16 & Cyt b6/f VIII & 12.89 & Unknown & 3.14 & PPCD VHS3-like & 20268 & 15399 & 108 & 5.68 & 8. \\
\hline $\begin{array}{l}\text { Aquilegia } \\
\text { coerulia } \\
\end{array}$ & 41063 & 620.28 & Unknown & 3.82 & Unknown & 12.74 & Unknown & 2.85 & Unknown & 23818 & 17169 & 76 & 5.64 & 8.2 \\
\hline $\begin{array}{l}\text { Arabidopsis } \\
\text { halleri }\end{array}$ & 26911 & 609.56 & Unknown & 3.18 & Unknown & 12.50 & Unknown & 3.10 & Unknown & 14727 & 12123 & 61 & 5.59 & 8. \\
\hline $\begin{array}{l}\text { Arabidopsis } \\
\text { lyrata }\end{array}$ & 39161 & 611.10 & Midasin & 2.51 & Unknown & 12.74 & 60S RP L41 & 2.85 & $\begin{array}{l}\text { RNA Pol. II Med } \\
17\end{array}$ & 22213 & 16854 & 94 & 5.62 & 8.4 \\
\hline $\begin{array}{l}\text { Arabidopsis } \\
\text { thaliana }\end{array}$ & 48350 & 611.88 & $\begin{array}{l}\text { Misin- } \\
\text { like } \\
\end{array}$ & 0.57 & Hypothetical & 12.74 & 60S RP L41 & 2.75 & $\begin{array}{l}\text { Glycine-rich } \\
\text { protein }\end{array}$ & 27305 & 20926 & 119 & 5.61 & 8. \\
\hline Arabis alpina & 23286 & 565.05 & Unknown & $* * *$ & $* * * *$ & 12.79 & Unknown & 2.14 & Unknown & 13427 & 9810 & 49 & 5.52 & 8. \\
\hline $\begin{array}{l}\text { Arachis } \\
\text { duranensis }\end{array}$ & 52826 & 617.77 & Misin & 4.11 & DDHGT 4A & 12.72 & PERK2 & 2.96 & Unknown & 29514 & 23184 & 128 & 5.67 & 8.2 \\
\hline Arachis ipaensis & 57621 & 617.63 & Misin & 4.08 & DDHGT 4A & 12.36 & Unknown & 3.13 & $\begin{array}{l}\text { Small acidic } \\
\text { protein }\end{array}$ & 31471 & 26007 & 143 & 5.67 & 8.2 \\
\hline $\begin{array}{l}\text { Asparagus } \\
\text { officinalis }\end{array}$ & 36763 & 608.71 & Misin & 4.28 & DDHGT 4A & 12.50 & protein TPRXL & 2.89 & FS CAYBR BP & 20748 & 15934 & 81 & 5.64 & 8.4 \\
\hline $\begin{array}{l}\text { Auxenochlorella } \\
\text { protothecoides }\end{array}$ & 7014 & 1649.26 & PKS & $* * *$ & $* * *$ & 13.21 & Mucin-I & 2.35 & $\begin{array}{l}\text { Hypothetical } \\
\text { protein }\end{array}$ & 4131 & 2874 & 9 & 5.52 & 8.6 \\
\hline $\begin{array}{l}\text { Bathycoccus } \\
\text { prasinos }\end{array}$ & 7900 & 1814.10 & Unnamed & 3.32 & Ycf12 & 12.74 & Unknown & 3.42 & Unknown & 4799 & 3093 & 8 & 5.47 & 8. \\
\hline Beta vulgaris & 32874 & 617.35 & Misin & 3.56 & Unknown & 12.55 & Proline-rich $\mathrm{P}$ & 3.16 & Shematrin-like 2 & 18770 & 14017 & 87 & 5.68 & 8.1 \\
\hline $\begin{array}{l}\text { Botrycoccus } \\
\text { braunii }\end{array}$ & 23685 & 522.853 & Unknown & 3.068 & Unknown & 12.82 & Unknown & 2.21 & Unknown & 11176 & 12439 & 70 & 5.61 & 8.6 \\
\hline $\begin{array}{l}\text { Brachipodium } \\
\text { stacei }\end{array}$ & 36357 & 605.43 & Unknown & 3.023 & Unknown & 12.88 & Unknown & 3.05 & Unknown & 19318 & 16954 & 85 & 5.67 & 8.5 \\
\hline $\begin{array}{l}\text { Brachipodium } \\
\text { sylvaticum }\end{array}$ & 50263 & 608.40 & Unknown & 3.14 & Unknown & 12.88 & Unknown & 3.00 & Unknown & 26022 & 24130 & 111 & 5.66 & $8 . \varepsilon$ \\
\hline $\begin{array}{l}\text { Brachipodium } \\
\text { distachyon }\end{array}$ & 33944 & 605.24 & Misin & 3.16 & Cyt b6/f VIII & 12.39 & Unknown & 3.03 & $\begin{array}{l}\text { Prothymosin } \alpha \text {-B- } \\
\text { like }\end{array}$ & 19814 & 14052 & 78 & 5.67 & 8. \\
\hline $\begin{array}{l}\text { Brachypodium } \\
\text { hybridum }\end{array}$ & 80980 & 605.62 & Unknown & 3.02 & Unknown & 13.14 & Unknown & 3.05 & Unknown & 40744 & 40092 & 144 & 5.66 & 8.7 \\
\hline Brassica napus & 123465 & 606.90 & $\begin{array}{l}\text { Misin- } \\
\text { like }\end{array}$ & 3.15 & petN & 12.57 & IQ domain 31 & 2.75 & Shematrin-like 2 & 68255 & 54929 & 281 & 5.62 & 8.2 \\
\hline Brassica oleracea & 56687 & 606.74 & Misin & 3.48 & Unknown & 12.54 & IQ domain 31 & 2.75 & Shematrin-like 2 & 31109 & 25432 & 146 & 5.62 & 8.4 \\
\hline Brassica rapa & 52553 & 607.93 & Misin & 3.33 & Unknown & 12.57 & IQ domain 31 & 2.48 & $\begin{array}{l}\text { Dentin- } \\
\text { sialophospho } \\
\text { Protein-like }\end{array}$ & 29429 & 23004 & 120 & 5.62 & 8.4 \\
\hline Cajanus cajan & 38965 & 619.70 & Misin & 3.42 & Cyt b6/f VIII & 12.44 & CLAVATA3/ESR & 2.82 & RPB1-like & 22092 & 16793 & 80 & 5.71 & 8.2 \\
\hline Camelina sativa & 107481 & 610.42 & \begin{tabular}{|l|} 
Misin- \\
like \\
\end{tabular} & 2.61 & $\begin{array}{l}\text { Peptide } \\
\text { POLARIS } \\
\end{array}$ & 12.72 & SARMP 2-like & 2.13 & TsetseEP-like & 60623 & 46584 & 274 & 5.61 & 8.2 \\
\hline $\begin{array}{l}\text { Capsella } \\
\text { grandiflora } \\
\end{array}$ & 26561 & 593.86 & Unknown & 3.41 & Unknown & 12.44 & Unknown & 2.80 & Unknown & 14831 & 11661 & 61 & 5.62 & 8. \\
\hline Capsella rubella & 34126 & 610.40 & Misin & 3.57 & Unknown & 12.44 & Lifeguard 1 & 3.13 & Unknown & 19477 & 14578 & 71 & 5.63 & 8.4 \\
\hline $\begin{array}{l}\text { Capsicum } \\
\text { annuum }\end{array}$ & 45410 & 617.56 & Misin & 3.16 & Cyt b6/f VIII & 12.79 & GRCW protein & 2.75 & GRCW protein 1 & 25339 & 19970 & 101 & 5.67 & 8. \\
\hline $\begin{array}{l}\text { Capsicum } \\
\text { baccatum }\end{array}$ & 35853 & 553.75 & \begin{tabular}{|l|} 
Auxin TP \\
BIG \\
\end{tabular} & 3.16 & Cyt b6/f VIII & 12.64 & Hypothetical & 1.99 & Hypothetical & 20479 & 15300 & 74 & 5.55 & 8.4 \\
\hline $\begin{array}{l}\text { Capsicum } \\
\text { chinense }\end{array}$ & 34973 & 550.87 & \begin{tabular}{|l|} 
Auxin TP \\
BIG \\
\end{tabular} & 3.16 & Cyt b6/f VIII & 13.21 & Hypothetical & 2.24 & Hypothetical & 20497 & 14398 & 79 & 5.56 & 8. \\
\hline Carica papaya & 26103 & 446.01 & Unknown & 3.16 & Cyt b6/f VIII & 12.29 & 50S RP L34 & 3.10 & $\begin{array}{l}\text { Small acidic } \\
\text { protein }\end{array}$ & 14512 & 11526 & 65 & 5.67 & 8.2 \\
\hline $\begin{array}{l}\text { Cephalotus } \\
\text { follicularis }\end{array}$ & 36667 & 611.81 & AAA_5 & $* * *$ & $* * * *$ & 13.04 & Hypothetical & 2.9 & Hypothetical & 18643 & 17959 & 65 & 5.66 & 8. \\
\hline $\begin{array}{l}\text { Chenopodium } \\
\text { quinoa }\end{array}$ & 63173 & 621.14 & \begin{tabular}{|l|} 
Misin- \\
like \\
\end{tabular} & 3.16 & petN & 12.22 & SR45-like & 3.02 & Unknown & 36037 & 26973 & 163 & 5.66 & 8.1 \\
\hline $\begin{array}{l}\text { Chlamydomonas } \\
\text { eustigma }\end{array}$ & 14161 & 1370.23 & Unknown & 2.28 & Unknown & 13.14 & Unknown & 2.18 & Unknown & 9089 & 5036 & 36 & 5.64 & 8. \\
\hline $\begin{array}{l}\text { Chlamydomonas } \\
\text { reinhardtii }\end{array}$ & 14488 & 2056.44 & PKS & 1.46 & Unknown & 13.34 & Unknown & 2.40 & Unknown & 7427 & 7029 & 32 & 5.64 & 8.7 \\
\hline $\begin{array}{l}\text { Chlorella } \\
\text { variabilis } \\
\end{array}$ & 9780 & 1159.35 & Unknown & 4.91 & Unknown & 12.73 & Unknown & 2.88 & Unknown & 5883 & 3876 & 21 & 5.55 & 8.5 \\
\hline $\begin{array}{l}\text { Chromochloris } \\
\text { zofingiensis } \\
\end{array}$ & 15369 & 1932.21 & Unknown & 2.34 & Unknown & 12.5 & Unknown & 2.54 & Unknown & 9592 & 5740 & 37 & 5.61 & 8. \\
\hline Cicer arietinum & 33107 & 616.07 & Unknown & 3.02 & Unknown & 12.25 & Unknown & 3.14 & Unknown & 19043 & 13979 & 85 & 5.69 & 8.4 \\
\hline $\begin{array}{l}\text { Citrus } \\
\text { clementina }\end{array}$ & 34557 & 588.15 & Unknown & $* * * *$ & $* * * *$ & 12.44 & Unknown & 2.95 & Unknown & 19332 & 15151 & 74 & 5.67 & 8.4 \\
\hline Citrus sinensis & 35648 & 617.00 & Misin & 3.16 & Cyt b6/f VIII & 12.25 & Unknown & 2.93 & $\begin{array}{l}\text { Circumsporozoite } \\
\text { protein-like }\end{array}$ & 20887 & 14680 & 81 & 5.69 & 8.1 \\
\hline Citrus unshiu & 37970 & 684.122 & Unknown & 0.54 & Unknown & 12.83 & Unknown & 2.74 & Unknown & 20954 & 16926 & 90 & 5.67 & 8. \\
\hline $\begin{array}{l}\text { Coccomyxa } \\
\text { subellipsoidea }\end{array}$ & 9839 & 1632.35 & $\begin{array}{l}\text { Ketoacyl- } \\
\text { synt }\end{array}$ & 5.06 & Unknown & 12.99 & Unknown & 3.05 & Unknown & 6112 & 3708 & 19 & 5.53 & 8.5 \\
\hline $\begin{array}{l}\text { Corchorus } \\
\text { capsularis } \\
\end{array}$ & 29356 & 606.73 & Unknown & 1.6 & Unknown & 12.74 & Unknown & 2.72 & IMP & 15540 & 13783 & 33 & 5.49 & 8.6 \\
\hline $\begin{array}{l}\text { Corchorus } \\
\text { olitorius }\end{array}$ & 35704 & 498.84 & ZRF & 2.79 & Unknown & 12.79 & Unknown & 2.56 & Unknown & 19280 & 16359 & 65 & 5.49 & 8.6 \\
\hline
\end{tabular}




\begin{tabular}{|c|c|c|c|c|c|c|c|c|c|c|c|c|c|c|}
\hline Cucumis melo & 29796 & 616.61 & Misin & 2.87 & Unknown & 13.23 & Unknown & 2.56 & Loricin-like & 17151 & 12562 & 83 & 5.7 & 8.2 \\
\hline Cucumis sativus & 29796 & 617.61 & Misin & 2.87 & Unknown & 13.23 & Unknown & 2.56 & Loricin-like & 17151 & 12562 & 83 & 5.7 & 8.2 \\
\hline $\begin{array}{l}\text { Cucurbita } \\
\text { maxima }\end{array}$ & 42777 & 615.95 & Misin & 3.58 & Unknown & 12.22 & 60S RP L39 & 2.54 & CWP gp 1-like & 24870 & 17817 & 90 & 5.68 & 8.2 \\
\hline $\begin{array}{l}\text { Cucurbita } \\
\text { moschata }\end{array}$ & 43715 & 615.32 & Misin & 4.1 & DDGT 4A & 12.85 & EPR1 & 2.31 & PKDP & 25399 & 18233 & 83 & 5.67 & 8.4 \\
\hline Daucus carota & 44655 & 619.12 & Misin & 3.16 & Cyt b6/f VIII & 12.32 & $\begin{array}{l}\text { Ribo Protein } \\
\text { L32 }\end{array}$ & 2.79 & Loricin & 26135 & 18423 & 97 & 5.68 & 8.1 \\
\hline $\begin{array}{l}\text { Dendrobium } \\
\text { officinale }\end{array}$ & 34527 & 616.94 & Misin & 3.16 & Cyt b6/f VIII & 12.45 & 60S RP L39 & 3.23 & Unknown & 19029 & 15425 & 73 & 5.69 & 8.2 \\
\hline $\begin{array}{l}\text { Dichanthelium } \\
\text { oligosanthes }\end{array}$ & 26468 & 538.41 & $\begin{array}{l}\text { Auxin TP } \\
\text { BIG }\end{array}$ & 1.09 & Unknown & 13.18 & Unknown & 3.00 & Unknown & 14146 & 12261 & 61 & 5.6 & 8.6 \\
\hline $\begin{array}{l}\text { Dorcoceras } \\
\text { hygrometricum }\end{array}$ & 47778 & 563.43 & Midasin & 4.75 & Unknown & 12.86 & Unknown & 2.68 & Unknown & 23461 & 24237 & 80 & 5.44 & 8.6 \\
\hline Dunaliella salina & 18801 & 603.54 & Unknown & 2.92 & Unknown & 12.69 & Unknown & 2.38 & Unknown & 9927 & 8833 & 41 & 5.66 & $8 . e^{5}$ \\
\hline Durio zibethinus & 63007 & 620.96 & Misin & 3.57 & Unknown & 12.35 & SR45-like & 3.12 & Acidic protein & 37032 & 25800 & 175 & 5.68 & 8.2 \\
\hline Elaeis guineensis & 41887 & 614.29 & Misin & 3.19 & Cyt b6/f VIII & 12.35 & 50S RP L34 & 3.28 & $\begin{array}{l}\text { Calsequestrin 1- } \\
\text { like }\end{array}$ & 24529 & 17266 & 92 & 5.69 & 8.2 \\
\hline $\begin{array}{l}\text { Erythranthe } \\
\text { guttata }\end{array}$ & 31861 & 611.80 & Misin & 3.77 & Unknown & 12.14 & SR45 & 2.6 & CSF subunit 2 & 18284 & 13500 & 77 & 5.63 & 8.2 \\
\hline $\begin{array}{l}\text { Eucalyptus } \\
\text { grandis }\end{array}$ & 52554 & 644.40 & Futsch & 3.4 & Cyt b6/f VIII & 12.83 & Unknown & 3.07 & Fimbrin 1-like & 31377 & 21034 & 143 & 5.69 & 8.2 \\
\hline $\begin{array}{l}\text { Eutrema } \\
\text { salsugineum }\end{array}$ & 29485 & 609.35 & Unknown & $* * *$ & $* * * *$ & 12.32 & Unknown & 3.05 & Unknown & 16105 & 13300 & 80 & 5.63 & 8. \\
\hline Fragaria vesca & 31387 & 609.82 & Misin & 3.19 & Cyt b6/f VIII & 12.34 & 50S RP L34 & 3.13 & $\begin{array}{l}\text { Prostatic } \\
\text { spermine BP }\end{array}$ & 18862 & 12429 & 96 & 5.65 & 8.2 \\
\hline Genlisea aurea & 17685 & 559.24 & Unknown & 4.94 & Unknown & 12.89 & Unknown & 2.93 & Unknown & 9842 & 7814 & 29 & 5.54 & 8.5 \\
\hline Glycine max & 71523 & 619.18 & $\begin{array}{l}\text { Misin- } \\
\text { like }\end{array}$ & 1.34 & AAPT & 12.28 & Unknown & 2.67 & HC1-like & 41545 & 29785 & 193 & 5.68 & 8.2 \\
\hline Glycine soja & 50399 & 603.79 & Misin & 1.59 & Hypothetical & 12.42 & Dynein & 2.21 & $\mathrm{RBP} 12 \mathrm{~B}$ & 28254 & 22054 & 91 & 5.62 & 8.8 \\
\hline $\begin{array}{l}\text { Gonium } \\
\text { pectorale }\end{array}$ & 16290 & 881.59 & Unknown & 5.02 & Unknown & 12.88 & Unknown & 2.48 & Unknown & 10225 & 6034 & 31 & 5.52 & 8.5 \\
\hline $\begin{array}{l}\text { Gossypium } \\
\text { arboreum }\end{array}$ & 47568 & 806.46 & Titin-like & 3.16 & Cyt b6/f VIII & 12.23 & SR45-like & 2.91 & Loricin-like & 26844 & 20612 & 103 & 5.69 & 8.2 \\
\hline $\begin{array}{l}\text { Gossypium } \\
\text { hirsutum }\end{array}$ & 90927 & 750.00 & Titin-like & 3.16 & Cyt b6/f VIII & 12.26 & SARMP 2-like & 2.67 & ER TF TINY-like & 51343 & 39336 & 248 & 5.67 & 8.2 \\
\hline $\begin{array}{l}\text { Gossypium } \\
\text { raimondii }\end{array}$ & 59057 & 802.74 & Titin-like & 3.16 & Cyt b6/f VIII & 12.25 & SR45 & 2.98 & $\begin{array}{l}\text { Arabinogalactan } \\
11\end{array}$ & 33377 & 25561 & 119 & 5.67 & 8.2 \\
\hline $\begin{array}{l}\text { Handroanthus } \\
\text { impetiginosus }\end{array}$ & 30271 & 475.38 & Unknown & 2.91 & Unknown & 12.66 & Unknown & 2.95 & Unknown & 16255 & 13959 & 57 & 5.64 & 8. \\
\hline $\begin{array}{l}\text { Helianthus } \\
\text { annuus }\end{array}$ & 73839 & 1300.83 & Unknown & 2.76 & Unknown & 12.88 & C1E8.05-like & 2.62 & $\begin{array}{l}\text { Prostatic } \\
\text { spermine BP }\end{array}$ & 40355 & 33310 & 174 & 5.63 & 8.2 \\
\hline $\begin{array}{l}\text { Helicosporidium } \\
\text { sp. }\end{array}$ & 6033 & 245.59 & Unknown & $* * *$ & $* * *$ & 12.79 & Unknown & 2.82 & Unknown & 3799 & 2226 & 8 & 5.32 & 8.6 \\
\hline $\begin{array}{l}\text { Herrania } \\
\text { umbratica }\end{array}$ & 27748 & 620.76 & Misin & 4.23 & DDGT 4A & 12.66 & Unknown & 3.12 & $\begin{array}{l}\text { Small acidic } \\
\text { protein } 1\end{array}$ & 16209 & 11492 & 47 & 5.7 & 8.2 \\
\hline $\begin{array}{l}\text { Hevea } \\
\text { brasiliensis }\end{array}$ & 58062 & 620.10 & Misin & 3.16 & Cyt b6/f VIII & 12.16 & 50S RP L35 & 3.12 & $\begin{array}{l}\text { Small acidic } \\
\text { protein } 1\end{array}$ & 33994 & 23952 & 116 & 5.69 & 8.2 \\
\hline $\begin{array}{l}\text { Hordeum } \\
\text { vulgare }\end{array}$ & 248180 & 607.08 & Unknown & 1.75 & Unknown & 13.11 & $* * * *$ & 2.52 & Unknown & 132250 & 115421 & 509 & 5.60 & 8.6 \\
\hline Ipomoea nil & 51054 & 636.34 & $\begin{array}{l}\text { Filaggrin- } \\
\text { like }\end{array}$ & 3.16 & Cyt b6/f VIII & 12.38 & Formin 2-like & 2.82 & Nucleolin-like & 29183 & 21727 & 144 & 5.69 & 8.1 \\
\hline Jatropha curcas & 32547 & 628.22 & Titin & 3.16 & petN & 12.14 & 60S RP L39-3 & 3.13 & $\begin{array}{l}\text { Glycin-rich } \\
\text { protein }\end{array}$ & 18939 & 13531 & 77 & 5.69 & 8.1 \\
\hline Juglans regia & 55627 & 624.15 & Midasin & 4.14 & 40S RP S29-like & 12.98 & Formin-like 3 & 2.46 & $\begin{array}{l}\text { Glycine-rich } \\
\text { protein }\end{array}$ & 32225 & 23292 & 110 & 5.69 & 8.2 \\
\hline $\begin{array}{l}\text { Kalanchoe } \\
\text { fedtschenkoi }\end{array}$ & 45190 & 563.28 & Unknown & 3.16 & Unknown & 12.98 & Unknown & 2.88 & Unknown & 25024 & 20062 & 104 & 5.64 & 8.8 \\
\hline $\begin{array}{l}\text { Kalanchoe } \\
\text { laxiflora }\end{array}$ & 69177 & 619.54 & Unknown & 3.01 & Unknown & 12.47 & Unknown & 3.09 & Unknown & 39148 & 29888 & 141 & 5.66 & 8. \\
\hline $\begin{array}{l}\text { Klebsormidium } \\
\text { nitens }\end{array}$ & 16282 & 813.31 & Unknown & *** & $* * *$ & 12.83 & $\begin{array}{l}\text { Ser/Thr Prot } \\
\text { Kin }\end{array}$ & 3.09 & Unknown & 9751 & 6500 & 31 & 5.57 & $8 . \bar{c}$ \\
\hline Lactuca sativa & 45242 & 609.98 & Misin & 3.16 & Cyt b6/f VIII & 12.44 & Glh-2-like & 2.56 & Ctenidin-3-like & 25604 & 19492 & 146 & 5.67 & 8.2 \\
\hline $\begin{array}{l}\text { Linum } \\
\text { usitatissimum }\end{array}$ & 43484 & 544.30 & Unknown & 4.95 & Unknown & 12.41 & Unknown & 2.49 & Unknown & 24926 & 18459 & 99 & 5.58 & 8. \\
\hline $\begin{array}{l}\text { Lupinus } \\
\text { angustifolius }\end{array}$ & 52821 & 619.31 & Misin & 5.59 & $\begin{array}{l}\text { Arabinogalactan } \\
\text { peptide } 23\end{array}$ & 13.07 & $\begin{array}{l}\text { Collagen } \\
\alpha-2(V) \text { chain- } \\
\text { like }\end{array}$ & 2.76 & $\begin{array}{l}\text { Glutamic acid } \\
\text { rich protein }\end{array}$ & 31045 & 21650 & 126 & 5.67 & 8.2 \\
\hline $\begin{array}{l}\text { Macleaya } \\
\text { cordata }\end{array}$ & 21911 & 624.74 & $\begin{array}{l}\text { Von } \\
\text { Willbrand } \\
\text { factor } \\
\end{array}$ & 3.87 & Unknown & 12.32 & Unknown & 2.94 & Unknown & 12657 & 9206 & 48 & 5.61 & 8.2 \\
\hline Malus domestica & 60544 & 551.44 & $\begin{array}{l}\text { Auxin TP } \\
\text { BIG }\end{array}$ & 3.45 & Unknown & 12.91 & CDPK & 2.79 & IFF6-like & 34853 & 25548 & 143 & 5.65 & 8.2 \\
\hline $\begin{array}{l}\text { Manihot } \\
\text { acuminata }\end{array}$ & 36528 & 516.85 & Unknown & 1.01 & Unknown & 12.88 & Unknown & 2.88 & Unknown & 18516 & 17936 & 76 & 5.64 & 8.5 \\
\hline $\begin{array}{l}\text { Manihot } \\
\text { esculenta }\end{array}$ & 43286 & 621.75 & Midasin & 3.16 & Cyt b6/f VIII & 12.19 & SR45-like & 2.65 & ASF1-like & 25698 & 17491 & 97 & 5.68 & 8.1 \\
\hline $\begin{array}{l}\text { Marchantia } \\
\text { polymorpha }\end{array}$ & 17956 & 806.12 & Unknown & 7.02 & Unknown & 12.10 & Unknown & 3.10 & Unknown & 10142 & 7793 & 21 & 5.54 & 8.4 \\
\hline $\begin{array}{l}\text { Medicago } \\
\text { truncatula }\end{array}$ & 57661 & 611.94 & Misin & 1.90 & NCR peptide & 12.74 & Unknown & 2.57 & LEA & 30526 & 27027 & 108 & 5.61 & 8.4 \\
\hline $\begin{array}{l}\text { Micromonas } \\
\text { commoda }\end{array}$ & 10137 & 1532.91 & PKS & 2.78 & $\begin{array}{l}\text { Antisense } \\
\text { noncoding }\end{array}$ & 12.61 & Unknown & 2.95 & Unknown & 6417 & 3703 & 17 & 5.4 & 8.6 \\
\hline $\begin{array}{l}\text { Micromonas } \\
\text { pusilla }\end{array}$ & 10242 & 848.29 & Unknown & 5.07 & Unknown & 13.37 & Unknown & 2.80 & Unknown & 5985 & 4242 & 15 & 5.37 & 8.6 \\
\hline $\begin{array}{l}\text { Miscanthus } \\
\text { sinensis }\end{array}$ & 89486 & 615.13 & Unknown & 2.90 & Unknown & 13.27 & Unknown & 2.88 & Unknown & 45710 & 43546 & 230 & 5.65 & 8.7 \\
\hline
\end{tabular}




\begin{tabular}{|c|c|c|c|c|c|c|c|c|c|c|c|c|c|c|}
\hline $\begin{array}{l}\text { Momordica } \\
\text { charantia }\end{array}$ & 28666 & 616.95 & Misin & 4.21 & DDG 4A & 12.22 & 60S RP L39 & 3.16 & $\begin{array}{l}\text { Small acidic } \\
\text { protein } 1\end{array}$ & 16621 & 11997 & 48 & 5.69 & 8.2 \\
\hline $\begin{array}{l}\text { Monoraphidium } \\
\text { neglectum }\end{array}$ & 16755 & 730.02 & Misin & 4.12 & Unknown & 13.01 & Unknown & 2.79 & Unknown & 8940 & 7783 & 32 & 5.44 & 8.6 \\
\hline Morus notabilis & 26965 & 566.71 & $\begin{array}{l}\text { Auxin TP } \\
\text { BIG }\end{array}$ & 5.11 & Unknown & 12.32 & Unknown & 3.10 & Unknown & 13932 & 12984 & 49 & 5.60 & 8.5 \\
\hline Musa acuminata & 47707 & 616.23 & Misin & 3.79 & DGG 4A & 12.44 & Unknown & 3.09 & TUB8 & 27400 & 20184 & 123 & 5.69 & 8.2 \\
\hline $\begin{array}{l}\text { Nelumbo } \\
\text { nucifera }\end{array}$ & 38191 & 797.88 & Titin & 3.16 & Cyt b6/f VIII & 12.22 & 60S RP L39 & 2.95 & $\begin{array}{l}\text { Prostatic } \\
\text { spermine BP }\end{array}$ & 22308 & 15782 & 101 & 5.70 & 8.2 \\
\hline $\begin{array}{l}\text { Nicotiana } \\
\text { attenuate }\end{array}$ & 44491 & 616.08 & Misin & 4.15 & DGG 4A & 12.19 & SR45 & 2.99 & Unknown & 23898 & 20492 & 101 & 5.67 & 8.2 \\
\hline $\begin{array}{l}\text { Nicotiana } \\
\text { sylvestris }\end{array}$ & 48160 & 564.57 & $\begin{array}{l}\text { Auxin TP } \\
\text { BIG }\end{array}$ & 1.30 & Unknown & 12.44 & Unknown & 2.95 & Unknown & 26496 & 21565 & 99 & 5.66 & 8.2 \\
\hline $\begin{array}{l}\text { Nicotiana } \\
\text { tabacum }\end{array}$ & 84255 & 539.85 & $\begin{array}{l}\text { Auxin TP } \\
\text { BIG }\end{array}$ & 3.16 & Cyt b6/f VIII & 12.44 & Unknown & 2.86 & $\begin{array}{l}\text { mRNA de cay } \\
\text { protein }\end{array}$ & 46302 & 37768 & 185 & 5.65 & 8.2 \\
\hline $\begin{array}{l}\text { Nicotiana } \\
\text { tomentosiformis }\end{array}$ & 48962 & 564.92 & $\begin{array}{l}\text { Aux TP } \\
\text { BIG }\end{array}$ & 3.18 & Cyt b6/f VIII & 12.25 & $\begin{array}{l}\text { Cell wall } \\
\text { protein }\end{array}$ & 3.09 & $\begin{array}{l}\text { Arabinogalactan } \\
\text { peptide 14-like }\end{array}$ & 27278 & 21567 & 117 & 5.67 & 8.2 \\
\hline Olea europaea & 58334 & 567.49 & Misin & 3.16 & Cyt b6/f VIII & 12.36 & Unknown & 3.18 & $\begin{array}{l}\text { Acidic protein 2- } \\
\text { like }\end{array}$ & 32519 & 25690 & 125 & 5.65 & 8.2 \\
\hline $\begin{array}{l}\text { Oryza } \\
\text { brachyantha }\end{array}$ & 26803 & 597.14 & Misin & 5.73 & Unknown & 12.44 & NFD6 & 3.03 & $\begin{array}{l}\text { Prostatic } \\
\text { spermine BP }\end{array}$ & 16083 & 10659 & 61 & 5.64 & 8. \\
\hline Oryza sativa & 37358 & 567.80 & Unknown & 3.22 & Unknown & 12.64 & Unknown & 2.65 & Unknown & 20560 & 16732 & 66 & 5.56 & 8.6 \\
\hline $\begin{array}{l}\text { Ostreococcus } \\
\text { lucimarinus }\end{array}$ & 7603 & 1994.71 & PKS & 4.12 & Cysteine protein & 12.36 & Unknown & 2.85 & Unknown & 4879 & 2711 & 13 & 5.40 & 8.6 \\
\hline $\begin{array}{l}\text { Ostreococcus } \\
\text { tauri }\end{array}$ & 7766 & 1237.34 & Unknown & 3.29 & Ycf12 & 12.32 & L39e & 3.28 & SVC & 4732 & 3018 & 16 & 5.47 & 8.6 \\
\hline Panicum hallii & 49825 & 608.88 & Unknown & 1.87 & Unknown & 13.07 & Unknown & 3.05 & Unknown & 24843 & 24878 & 104 & 5.68 & $8 . ;$ \\
\hline $\begin{array}{l}\text { Phalaenopsis } \\
\text { equestris }\end{array}$ & 29894 & 568.40 & $\begin{array}{l}\text { Auxin TP } \\
\text { BIG }\end{array}$ & 3.20 & Cyt b6/f VIII & 12.5 & 50S L34 & 2.75 & Unknown & 16701 & 13099 & 94 & 5.69 & 8.2 \\
\hline $\begin{array}{l}\text { Phaseolus } \\
\text { vulgaris }\end{array}$ & 32720 & 617.41 & Unknown & $* * *$ & $* * *$ & 12.74 & Unknown & 3.09 & Unknown & 18577 & 14073 & 70 & 5.68 & 8.2 \\
\hline $\begin{array}{l}\text { Phoenix } \\
\text { dactylifera }\end{array}$ & 38570 & 617.67 & Misin & 3.19 & Cyt b6/f & 12.45 & 60S RP 139 & 3.31 & PPCD VHS3-like & 22015 & 16450 & 105 & 5.67 & 8. \\
\hline $\begin{array}{l}\text { Physcomitrella } \\
\text { patens }\end{array}$ & 35934 & 553.40 & Unknown & 3.21 & Unknown & 12.72 & Unknown & 2.77 & Unknown & 19655 & 16205 & 74 & 5.60 & 8.4 \\
\hline $\begin{array}{l}\text { Populus } \\
\text { deltoides }\end{array}$ & 57249 & 567.25 & Unknown & 3.14 & Unknown & 12.54 & Unknown & 2.85 & Unknown & 31040 & 26084 & 125 & 5.64 & 8. \\
\hline $\begin{array}{l}\text { Populus } \\
\text { euphratica }\end{array}$ & 49760 & 619.99 & Misin & 3.16 & Cyt b6/f & 12.22 & 60S RP L39 & 3.02 & $\begin{array}{l}\text { Calsequestrin-1- } \\
\text { like }\end{array}$ & 29358 & 20278 & 124 & 5.68 & 8.1 \\
\hline $\begin{array}{l}\text { Populust } \\
\text { richocarpa }\end{array}$ & 45942 & 603.68 & Misin & $* * *$ & *** & 12.74 & Unknown & 2.54 & Unknown & 25431 & 20413 & 98 & 5.62 & 8. \\
\hline $\begin{array}{l}\text { Porphyra } \\
\text { umbilicalis }\end{array}$ & 13360 & 480.60 & Unknown & 3.18 & Cyt b6/f & 13.33 & Unknown & 2.6 & Unknown & 3982 & 9365 & 13 & 5.47 & 10 \\
\hline Prunus avium & 35009 & 607.05 & Misin & 3.84 & Unknown & 12.22 & SR45 & 2.86 & Unknown & 20962 & 13972 & 75 & 5.68 & 8.1 \\
\hline Prunus mume & 29705 & 678.34 & Unknown & 3.19 & Cyt b6/f VIII & 12.22 & 60S RP L39 & 2.54 & $\begin{array}{l}\text { Cell wall protein } \\
\text { gp1 }\end{array}$ & 17588 & 12054 & 63 & 5.68 & 8.2 \\
\hline Prunus persica & 32595 & 607.17 & Misin & 3.19 & Cyt b6/f VIII & 12.22 & SR45 & 2.98 & SCP SP60-like & 19315 & 13201 & 79 & 5.70 & 8.1 \\
\hline Punica granatum & 50476 & 1150.02 & Unknown & 1.21 & Unknown & 13.96 & Unknown & 2.07 & Unknown & 23078 & 27314 & 84 & 5.52 & 8.6 \\
\hline $\begin{array}{l}\text { Pyrus } \\
\text { bretschneideri }\end{array}$ & 47086 & 1269.42 & Unknown & 4.13 & Unknown & 12.23 & 50S RP L34 & 3.10 & Unknown & 27610 & 19365 & 111 & 5.67 & 8.2 \\
\hline $\begin{array}{l}\text { Raphanus } \\
\text { sativus }\end{array}$ & 61216 & 607.96 & Misin & 2.89 & Unknown & 12.58 & IQ domain 31 & 2.79 & Shematrin-like 2 & 34204 & 26871 & 141 & 5.61 & 8. \\
\hline $\begin{array}{l}\text { Ricinus } \\
\text { communis }\end{array}$ & 27998 & 619.84 & Misin & 3.16 & Cyt b6/f VIII & 12.47 & Unknown & 3.12 & $\begin{array}{l}\text { Small acidic } \\
\text { protein }\end{array}$ & 16138 & 11789 & 71 & 5.68 & 8.2 \\
\hline Salix purpurea & 61520 & 621.82 & Unknown & 3.26 & Unknown & 12.61 & Unknown & 2.77 & Unknown & 35045 & 26358 & 117 & 5.64 & 8.4 \\
\hline $\begin{array}{l}\text { Selaginella } \\
\text { moellendorffii }\end{array}$ & 34746 & 909.93 & Unknown & 5.18 & Unknown & 12.45 & Unknown & 3.28 & Unknown & 20404 & 14243 & 99 & 5.66 & 8.2 \\
\hline $\begin{array}{l}\text { Sesamum } \\
\text { indicum }\end{array}$ & 35410 & 614.62 & Misin & 3.16 & Cyt b6/f VIII & 12.64 & L32 & 2.88 & BCP1-like & 20353 & 14974 & 83 & 5.68 & 8.2 \\
\hline Setaria italica & 35844 & 608.65 & Misin & 3.16 & Cyt b6/f VIII & 12.44 & NFD6 & 3.13 & \begin{tabular}{|l|} 
Prostatic \\
spermine BP \\
\end{tabular} & 20727 & 15027 & 90 & 5.7 & 8. \\
\hline $\begin{array}{l}\text { Solanum } \\
\text { lycopersicum }\end{array}$ & 36008 & 620.33 & Misin & 3.16 & Cyt b6/f VIII & 12.29 & SR45 & 2.46 & Cell wall protein & 21001 & 14925 & 82 & 5.67 & 8.2 \\
\hline $\begin{array}{l}\text { Solanum } \\
\text { pennellii }\end{array}$ & 35068 & 620.19 & Misin & 3.66 & Unknown & 12.16 & SR45 & 2.20 & Myb-like & 19944 & 15043 & 81 & 5.67 & 8.2 \\
\hline $\begin{array}{l}\text { Solanum } \\
\text { tuberosum }\end{array}$ & 37960 & 618.76 & Misin & 3.16 & Cyt b6/f VIII & 13.24 & Extension-like & 2.95 & $\begin{array}{l}\text { Tripartite motif } \\
44\end{array}$ & 22261 & 15614 & 85 & 5.67 & 8.1 \\
\hline Sorghum bicolor & 39248 & 615.07 & Misin & 3.16 & Cyt b6/f VIII & 12.57 & Unknown & 3.00 & Unknown & 21947 & 17200 & 101 & 5.68 & 8.4 \\
\hline Sphagnum fallax & 32298 & 1027.64 & Unknown & 3.19 & Unknown & 12.19 & Unknown & 2.62 & Unknown & 19972 & 12256 & 70 & 5.61 & 8. \\
\hline $\begin{array}{l}\text { Spinacia } \\
\text { oleracea }\end{array}$ & 32794 & 615.44 & Misin & 2.50 & SpolCp151 & 12.42 & EPR1 & 2.56 & Unknown & 18350 & 14357 & 87 & 5.66 & 8.2 \\
\hline $\begin{array}{l}\text { Spirodela } \\
\text { polyrhiza }\end{array}$ & 19623 & 596.16 & Unknown & 3.16 & Cyt b6/f VIII & 12.69 & Unknown & 2.74 & Unknown & 10680 & 8903 & 40 & 5.60 & 8.5 \\
\hline $\begin{array}{l}\text { Tarenaya } \\
\text { hassleriana }\end{array}$ & 41094 & 614.85 & Midasin & 4.03 & Unknown & 12.41 & IQ-domain 14 & 3.04 & Unknown & 23230 & 17762 & 102 & 5.65 & 8.2 \\
\hline $\begin{array}{l}\text { Theobroma } \\
\text { cacao }\end{array}$ & 30854 & 621.12 & Midasin & 3.16 & Cyt b6/f VIII & 12.21 & SR45 & 3.12 & $\begin{array}{l}\text { Small acidic } \\
\text { protein }\end{array}$ & 17897 & 12869 & 88 & 5.70 & 8.2 \\
\hline $\begin{array}{l}\text { Trifolium } \\
\text { pratense }\end{array}$ & 63799 & 566.60 & $\begin{array}{l}\text { Auxin TP } \\
\text { BIG }\end{array}$ & *** & *** & 12.88 & Unknown & 2.34 & Unknown & 37487 & 26211 & 101 & 5.36 & 8.4 \\
\hline $\begin{array}{l}\text { Trifolium } \\
\text { subterraneum }\end{array}$ & 42059 & 571.83 & Unknown & $* * *$ & *** & 12.33 & Unknown & 2.6 & Unknown & 24271 & 17701 & 87 & 5.28 & 8.2 \\
\hline $\begin{array}{l}\text { Triticum } \\
\text { aestivum }\end{array}$ & 250 & 230.08 & Unknown & 6.54 & Unknown & 12.15 & Unknown & 3.75 & Unknown & 147 & 103 & 0 & 5.59 & 8.2 \\
\hline Triticum urartu & 24169 & 559.02 & UBR4 & 4.5 & Unknown & 13.27 & Unknown & 2.96 & Unknown & 13783 & 10339 & 47 & 5.56 & 8.5 \\
\hline Vigna angularis & 37769 & 621.26 & Midasin & 2.96 & Unknown & 12.22 & 50S RP L34 & 2.81 & $\begin{array}{l}\text { Clumping factor } \\
\text { A }\end{array}$ & 21862 & 15798 & 109 & 5.7 & 8.2 \\
\hline Vigna radiata & 42284 & 624.61 & Midasin & 3.16 & Cyt b6/f VIII & 12.41 & Formin-like 6 & 2.89 & ATF7IP & 24545 & 17654 & 83 & 5.69 & 8.2 \\
\hline
\end{tabular}




\begin{tabular}{|c|c|c|c|c|c|c|c|c|c|c|c|c|c|c|}
\hline $\begin{array}{l}\text { Vinga } \\
\text { unguiculata }\end{array}$ & 42287 & 616.90 & Unknown & 3.17 & Cyt b6/f VIII & 12.91 & Unknown & 2.95 & Unknown & 24082 & 18103 & 102 & 5.69 & $8 . \varepsilon^{2}$ \\
\hline Vitis vinifera & 41208 & 622.14 & Midasin & 3.16 & Cyt b6/f VIII & 12.19 & Orf19 & 3.23 & Circumsporozite & 25295 & 15837 & 76 & 5.70 & 8.1 \\
\hline Volvox carteri & 14436 & 2236.80 & $\begin{array}{l}\text { Putative } \\
\text { PKS I }\end{array}$ & 4.89 & Unknown & 13.79 & Unknown & 2.42 & Unknown & 7560 & 6849 & 27 & 5.64 & 8.5 \\
\hline Zostera marina & 20450 & 606.86 & $* * * * * * *$ & 1.68 & ********* & 12.75 & $* * * * *$ & 2.42 & $* * * * *$ & 10988 & 9417 & 45 & 5.61 & 8. \\
\hline Average & 40469.47 & 707.23 & & & & 12.62 & & & & 22820 & 17794.26 & 91.36 & 5.62 & 8. \\
\hline
\end{tabular}

\section{Table 2}

Abundance of various amino acids in different species. The second column represents the average abundance whereas the third and fourth column represent variation (high and low) in amino acid composition in different species from the average. 


\begin{tabular}{|c|c|c|c|}
\hline $\begin{array}{l}\text { Amino } \\
\text { Acids }\end{array}$ & $\begin{array}{c}\text { Average } \\
\text { abundance } \\
(\%)\end{array}$ & High Abundance (\%) & Low Abundance (\%) \\
\hline Ala & 7.68 & $\begin{array}{l}\text { Porphyra umbilicalis (17.58), Monoraphidium neglectum } \\
\text { (16.58), Gonium pectorale (15.45), Chlorella variabilis } \\
\text { (15.15), Chlamydomonas reinhardtii (14.57), Micromonas } \\
\text { pusilla (14.20), Auxenochlorella protothecoides (13.69), } \\
\text { Volvox carteri (13.29), Helicosporidium sp. (12.75), } \\
\text { Micromonas commoda (12.61), Coccomyxa subellipsoidea } \\
\text { (12.29), Ostreococcus lucimarinus (11.89), Chromochloris } \\
\text { zofingiensis (11.57), Dunaliella salina (11.53), Ostreococcus } \\
\text { tauri (11.47), Klebsormidium nitens (10.62), Botrycoccus } \\
\text { braunii (9.86), Dichanthelium oligosanthes (9.71), } \\
\text { Chlamydomonas eustigma (9.53) }\end{array}$ & $\begin{array}{l}\text { Picea glauca (5.12), Medicago truncatula (5.8), } \\
\text { Lactua sativa (5.81), Zostera marina (5.86) }\end{array}$ \\
\hline Asp & 5.32 & $\begin{array}{l}\text { Micromonas pusilla (6.68), Micromonas commode (6.46), } \\
\text { Ostreococcus lucimarinus (6.38), Ostreococcus tauri (6.33), } \\
\text { Bathycoccus prasinos (6.05) }\end{array}$ & $\begin{array}{l}\text { Picea glauca (3.46), Dunaliella salina (4.28), } \\
\text { Chlorella variabilis (4.41), Chlamydomonas } \\
\text { reinhardtii (4.61), Porphyra umbilicalis (4.63), } \\
\text { Volvox carteri }(4.71), \text { Monoraphidium } \\
\text { neglectum }(4.71), \text { Botrycoccus braunii (4.78), } \\
\text { Gonium pectorale }(4.78)\end{array}$ \\
\hline Glu & 6.43 & $\begin{array}{l}\text { Bathycoccus prasinos }(8.44), \text { Klebsormidium nitens }(7.2) \text {, } \\
\text { Ostreococcus tauri (7.18), Ostreococcus lucimarinus (7.03) }\end{array}$ & $\begin{array}{l}\text { Porphyra umbilicalis (3.52), Picea glauca (4.02), } \\
\text { Chromochloris zofingiensis (4.66), } \\
\text { Chlamydomonas reinhardtii (5.15), Volvox } \\
\text { carteri (5.21), Monoraphidium neglectum (5.35) }\end{array}$ \\
\hline Phe & 3.97 & Arachis duranensis (6.18) & $\begin{array}{l}\text { Porphyra umbilicalis (2.01), Gonium pectorale } \\
\text { (2.4), Monoraphidium neglectum (2.44), Volvox } \\
\text { carteri (2.49), Dunaliella salina (2.56), } \\
\text { Chromochloris zofingiensis (2.58), } \\
\text { Chlamydomonas reinhardtii (2.59), Chlorella } \\
\text { variabilis (2.68), Chlamydomonas eustigma } \\
\text { (2.89), Auxenochlorella protothecoides (2.92) }\end{array}$ \\
\hline Gly & 6.80 & $\begin{array}{l}\text { Porphyra umbilicalis (11.76), Monoraphidium neglectum } \\
\text { (10.51), Gonium pectorale (10.33), Chlamydomonas } \\
\text { reinhardtii (9.58), Volvox carteri (9.54), Chlorella variabilis } \\
\text { (9.23), Auxenochlorella protothecoides (8.82), Micromonas } \\
\text { commoda (8.81), Micromonas pusilla (8.59), Klebsormidium } \\
\text { nitens }(8.44), \text { Helicosporidium sp. (8.29), Dunaliella salina } \\
(8.11), \text { Botrycoccus braunii }(8.03)\end{array}$ & Arachis duranensis (4.19) \\
\hline His & 2.4 & Dunaliella salina (3.13) & $\begin{array}{l}\text { Bathycoccus prasinos (1.87), Ostreococcus tauri } \\
\text { (1.93), Monoraphidium neglectum (1.93), } \\
\text { Micromonas pusilla (1.94), Ostreococcus } \\
\text { lucimarinus (1.96) }\end{array}$ \\
\hline Ile & 4.94 & Zostera marina (6.09) & $\begin{array}{l}\text { Porphyra umbilicalis (1.77), Monoraphidium } \\
\text { neglectum (2.34), Gonium pectorale (2.37), } \\
\text { Chlorella variabilis (2.52), Chlamydomonas } \\
\text { reinhardtii (2.60), Volvox carteri (2.78), } \\
\text { Helicosporidium sp. (2.80), Dunaliella salina } \\
\text { (2.82), Auxenochlorella protothecoides (2.96), } \\
\text { Micromonas pusilla (2.98) }\end{array}$ \\
\hline Lys & 5.73 & Bathycoccus prasinos (7.33) & $\begin{array}{l}\text { Porphyra umbilicalis (2.08), Gonium pectorale } \\
\text { (2.79), Monoraphidium neglectum (2.86), } \\
\text { Volvox carteri (3.03), Auxenochlorella } \\
\text { protothecoides (3.06), Chlorella variabilis } \\
\text { (3.06), Chlamydomonas reinhardtii (3.07), } \\
\text { Helicosporidium sp. (3.17), Dunaliella salina } \\
\text { (3.39) }\end{array}$ \\
\hline Leu & 9.62 & Picea glauca (13.12) & $\begin{array}{l}\text { Porphyra umbilicalis (7.07), Micromonas pusilla } \\
\text { (7.70), Bathycoccus prasinos (7.85), } \\
\text { Micromonas commoda (7.98), Ostreococcus } \\
\text { tauri (8.18), Ostreococcus lucimarinus (8.41) }\end{array}$ \\
\hline Met & 2.40 & Picea glauca (3.75) & $\begin{array}{l}\text { Porphyra umbilicalis (1.45), Monoraphidium } \\
\text { neglectum (1.78), Klebsormidium nitens (1.84), } \\
\text { Auxenochlorella protothecoides (1.95), Gonium } \\
\text { pectorale (1.97), Chlorella variabilis (1.98), } \\
\text { Micromonas pusilla (1.98), Helicosporidium sp. } \\
\text { (1.99) }\end{array}$ \\
\hline Asn & 4.13 & Medicago truncatula (5.09) & $\begin{array}{l}\text { Porphyra umbilicalis (1.53), Monoraphidium } \\
\text { neglectum (1.88), Chlorella variabilis (1.93), } \\
\text { Auxenochlorella protothecoides (2.02), Gonium } \\
\text { pectorale (2.11), Helicosporidium sp. (2.15), } \\
\text { Chlamydomonas reinhardtii (2.38), Micromonas } \\
\text { pusilla (2.49), Volvox carteri (2.49), Dunaliella } \\
\text { salina (2.61), Micromonas commoda (2.71), } \\
\text { Coccomyxa subellipsoidea (2.75), } \\
\text { Klebsormidium nitens (2.82), Botrycoccus } \\
\text { braunii (2.89), Ostreococcus tauri (2.93), } \\
\text { Ostreococcus lucimarinus (2.99) }\end{array}$ \\
\hline Pro & 5.10 & $\begin{array}{l}\text { Porphyra umbilicalis (9.2), Botrycoccus braunii (7.10), } \\
\text { Dunaliella salina (7.08), Volvox carteri (7.00), Gonium } \\
\text { pectorale (6.85), Chlamydomonas reinhardtii (6.49), Picea } \\
\text { glauca (6.45), Chlorella variabilis (6.41), Monoraphidium } \\
\text { neglectum (6.40), Auxenochlorella protothecoides (6.25), } \\
\text { Klebsormidium nitens (6.11) }\end{array}$ & Bathycoccus prasinos (3.81) \\
\hline
\end{tabular}




\begin{tabular}{|c|c|c|c|}
\hline Gln & 3.74 & $\begin{array}{l}\text { Dunaliella salina (7.00), Chromochloris zofingiensis }(6.20), \\
\text { Monoraphidium neglectum (5.60), Chlorella variabilis (5.56), } \\
\text { Chlamydomonas eustigma (4.83), Sphagnum fallax (4.67), } \\
\text { Coccomyxa subellipsoidea (4.59), Volvox carteri }(4.46), \\
\text { Botrycoccus braunii (4.35), Chlamydomonas reinhardtii } \\
\text { (4.28), Physcomitrella patens (4.08), Dorcoceras } \\
\text { hygrometricum (4.04), Klebsormidium nitens }(4.03)\end{array}$ & $\begin{array}{l}\text { Porphyra umbilicalis (2.04), Micromonas pusilla } \\
\text { (2.06), Micromonas commoda (2.58), } \\
\text { Ostreococcus tauri (2.58), Ostreococcus } \\
\text { lucimarinus (2.64) }\end{array}$ \\
\hline Arg & 5.68 & $\begin{array}{l}\text { Porphyra umbilicalis (9.81), Micromonas pusilla (8.12), } \\
\text { Ostreococcus tauri (7.96), Helicosporidium sp. (7.74), } \\
\text { Micromonas commoda (7.65), Ostreococcus lucimarinus } \\
\text { (7.46), Auxenochlorella protothecoides (7.13) }\end{array}$ & $\begin{array}{l}\text { Medicago truncatula (4.84), Trifolium pratense } \\
\text { (4.95), Cicer arietinum (4.97), Lactuca sativa } \\
\text { (4.99) }\end{array}$ \\
\hline Ser & 8.71 & Chlamydomonas eustigma (9.72) & $\begin{array}{l}\text { Monoraphidium neglectum (6.33), Chlorella } \\
\text { variabilis (6.44), Auxenochlorella } \\
\text { protothecoides (6.49), Porphyra umbilicalis } \\
\text { (6.52), Micromonas commoda (6.57), } \\
\text { Ostreococcus lucimarinus (6.72), Micromonas } \\
\text { pusilla }(6.74), \text { Gonium pectorale (7.06), } \\
\text { Chlamydomonas reinhardtii (7.11) }\end{array}$ \\
\hline Thr & 4.90 & $\begin{array}{l}\text { Chromochloris zofingiensis (5.80), Ostreococcus tauri (5.77), } \\
\text { Bathycoccus prasinos (5.72), Ostreococcus lucimarinus } \\
\text { (5.70), Chlamydomonas eustigma (5.44), Porphyra } \\
\text { umbilicalis (5.39), Micromonas pusilla (5.33), Volvox carteri } \\
(5.30)\end{array}$ & \\
\hline Val & 6.55 & $\begin{array}{l}\text { Ostreococcus tauri (7.42), Ostreococcus lucimarinus (7.35), } \\
\text { Porphyra umbilicalis (7.32), Micromonas commoda (7.22), } \\
\text { Helicosporidium sp. (7.20), Micromonas pusilla (7.11) }\end{array}$ & Picea glauca (5.26), Dunaliella salina (5.78) \\
\hline
\end{tabular}

\section{Table 3}

Average abundance of different amino acids in plant proteome. Leu was high abundant whereas Trp was the low abundant amino acid in the plant kingdom. The average amino acid composition includes 5.8 million protein sequences from 145 plant species. 


\begin{tabular}{lll}
\hline \multicolumn{1}{c}{ Biosynthetic pathways/Substrate } & Amino acids & Average abundance (\%) in Proteome \\
\hline$\alpha$-Ketoglutarate & Arginine & 6.68 \\
& Glutamate & 6.43 \\
& Glutamine & 3.74 \\
& Proline & 5.10 \\
\hline Pyruvate & Alanine & 7.68 \\
& Isoleucine & 4.94 \\
& Leucine & 9.62 \\
& Valine & 6.55 \\
\hline 3-Phosphoglycerate & Glycine & 6.80 \\
& Cysteine & 1.85 \\
\hline Oxaloacetate & Serine & 8.71 \\
& Asparagine & 4.13 \\
& Aspartate & 5.32 \\
\hline Phosphoenolpyruvate \& Erythrose 4-phosphate & Lysine & 5.73 \\
& Methionine & 2.40 \\
\hline Ribose 5-phosphate & Threonine & 4.90 \\
\hline & Phenylalanine & 3.97 \\
& Tryptophan & 1.28 \\
\hline
\end{tabular}

\section{Supplementary Data Legend}

\section{Supplementary File 1}

Supplementary file containing average amino acid composition of plant proteomes. The file is present in excel sheet and individual sheet represents details of different amino acid.

\section{Figures}




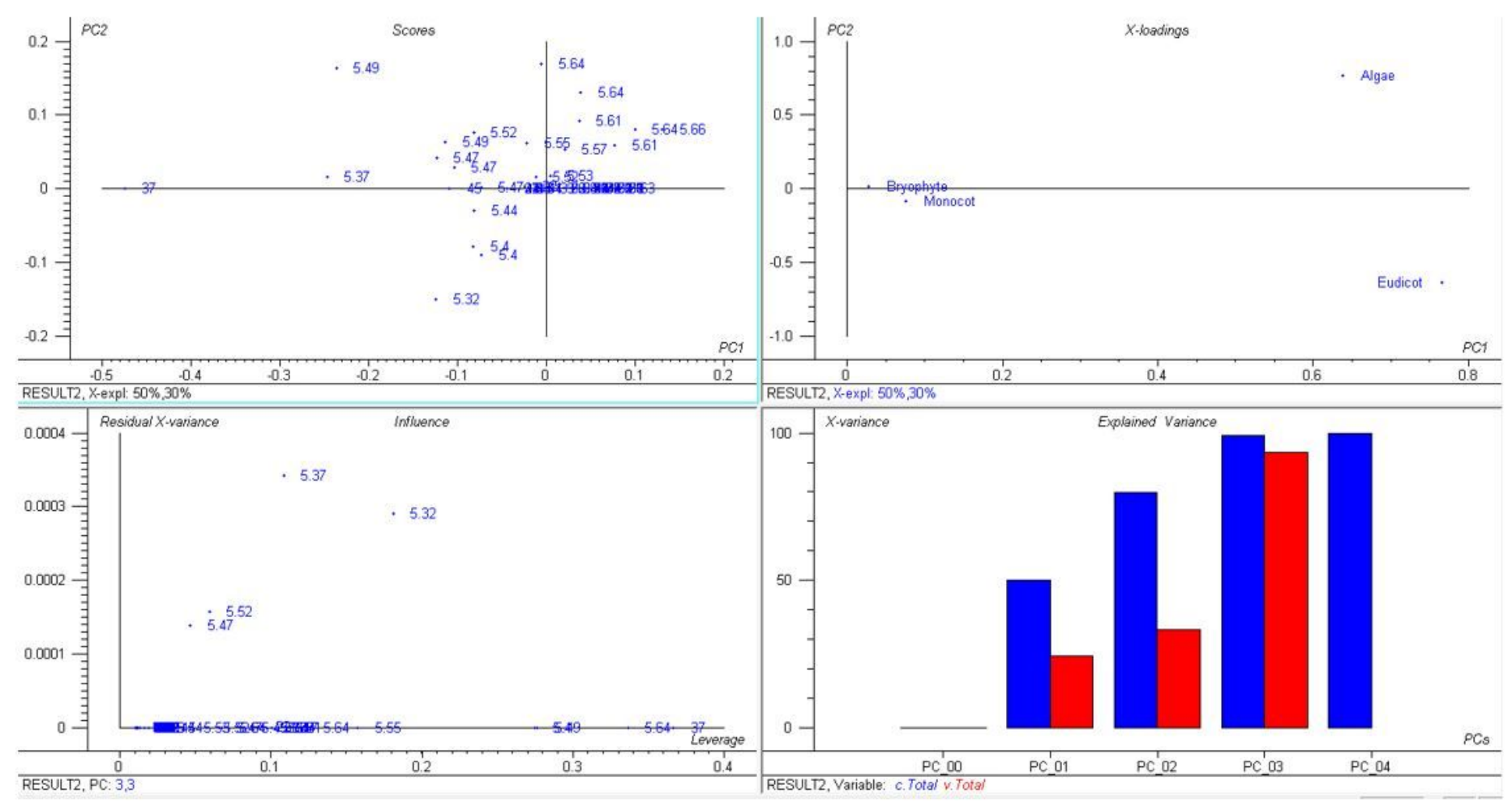

\section{Figure 1}

Principal component analysis (PCA) of acidic pl proteins. The PCA plot illustrates the relationship between the acidic pl of bryophytes and monocot plants which exhibit a linear correlation relative to algae and eudicots.
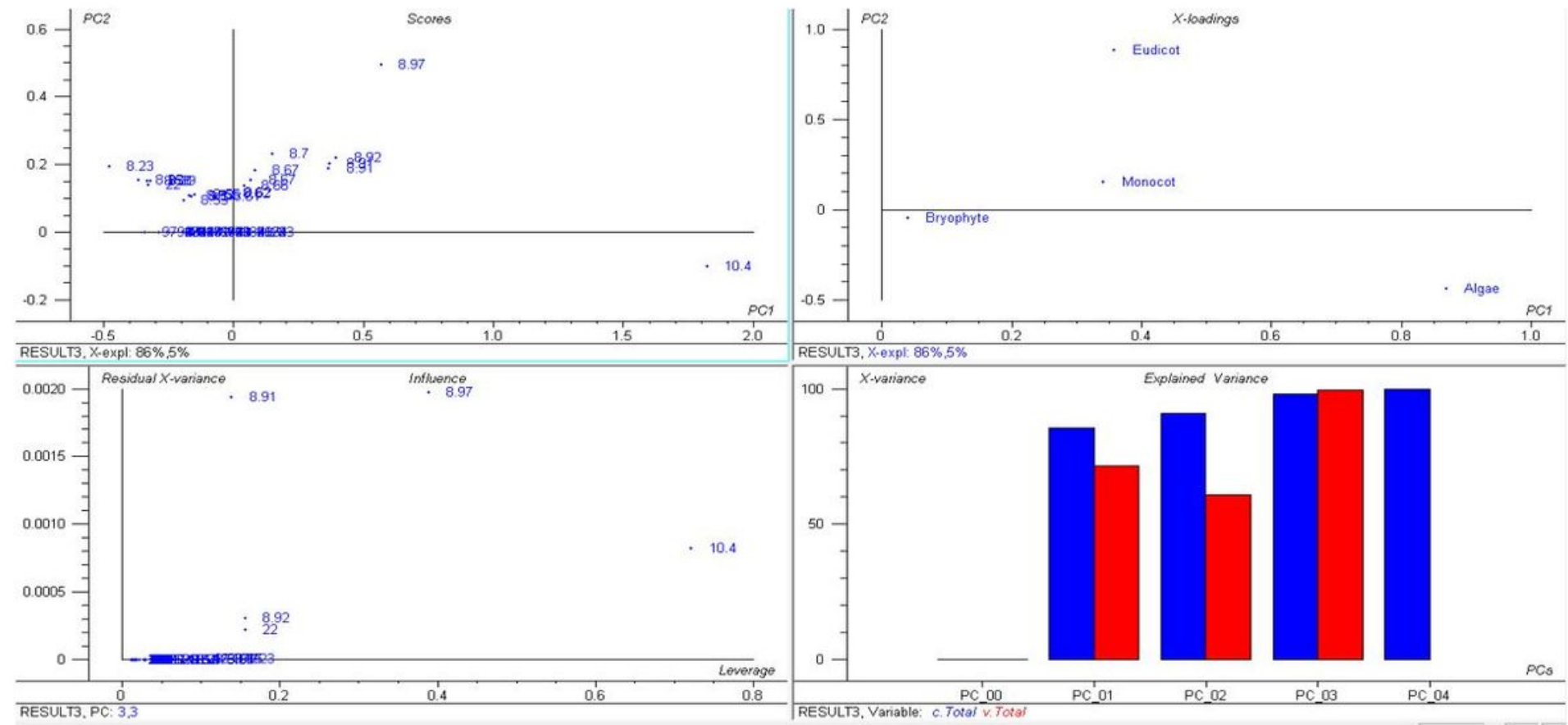

Figure 2

Principal component analysis (PCA) of basic pl proteins. The PCA plot illustrates that the basic pl of algae, bryophytes, eudicots, and monocot plants cluster distinctly from each other and that there is no lineage-specific correlation with basic pl proteins. 


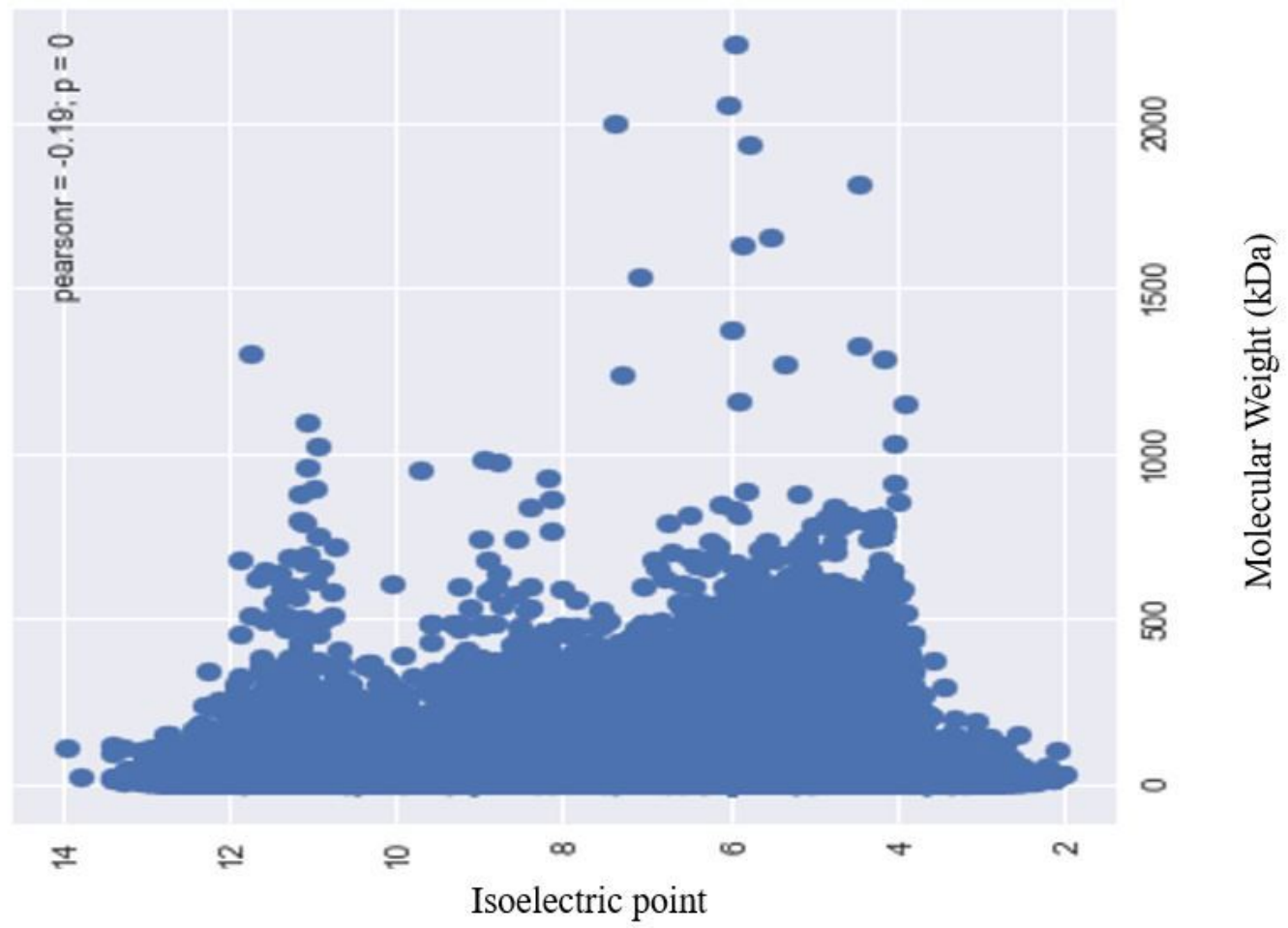

Figure 3

Trimodal distribution of isoelectric points $(\mathrm{pl})$ and the molecular mass $(\mathrm{kDa})$ of plant proteins. The pl of plant proteins ranged from 1.99 (epsin) to 13.96 (hypothetical protein), while the molecular mass ranged from 0.54 (unknown) to 2236.8 (type I polyketide synthase) kDa. The X-axis represents the pl and the $\mathrm{Y}$ - axis represents the molecular mass of the proteins.

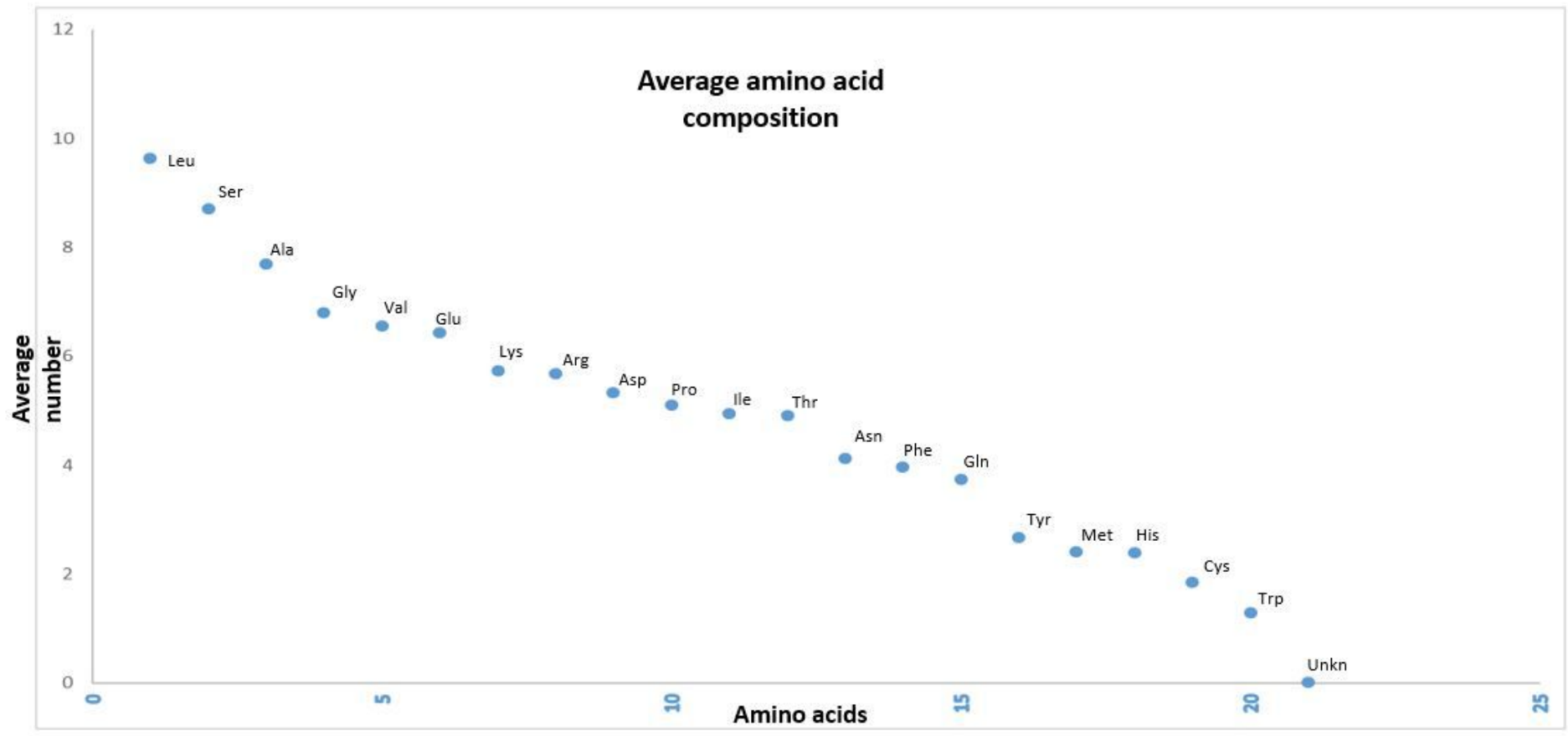

Figure 4

Average amino acid composition of proteins in the plant kingdom. Leu is the most abundant while Trp is the least abundant. The amino acid, Sec, was only found in a few species of algae and was absent from all other species. Ambiguous amino acids were found in a few species as well. 


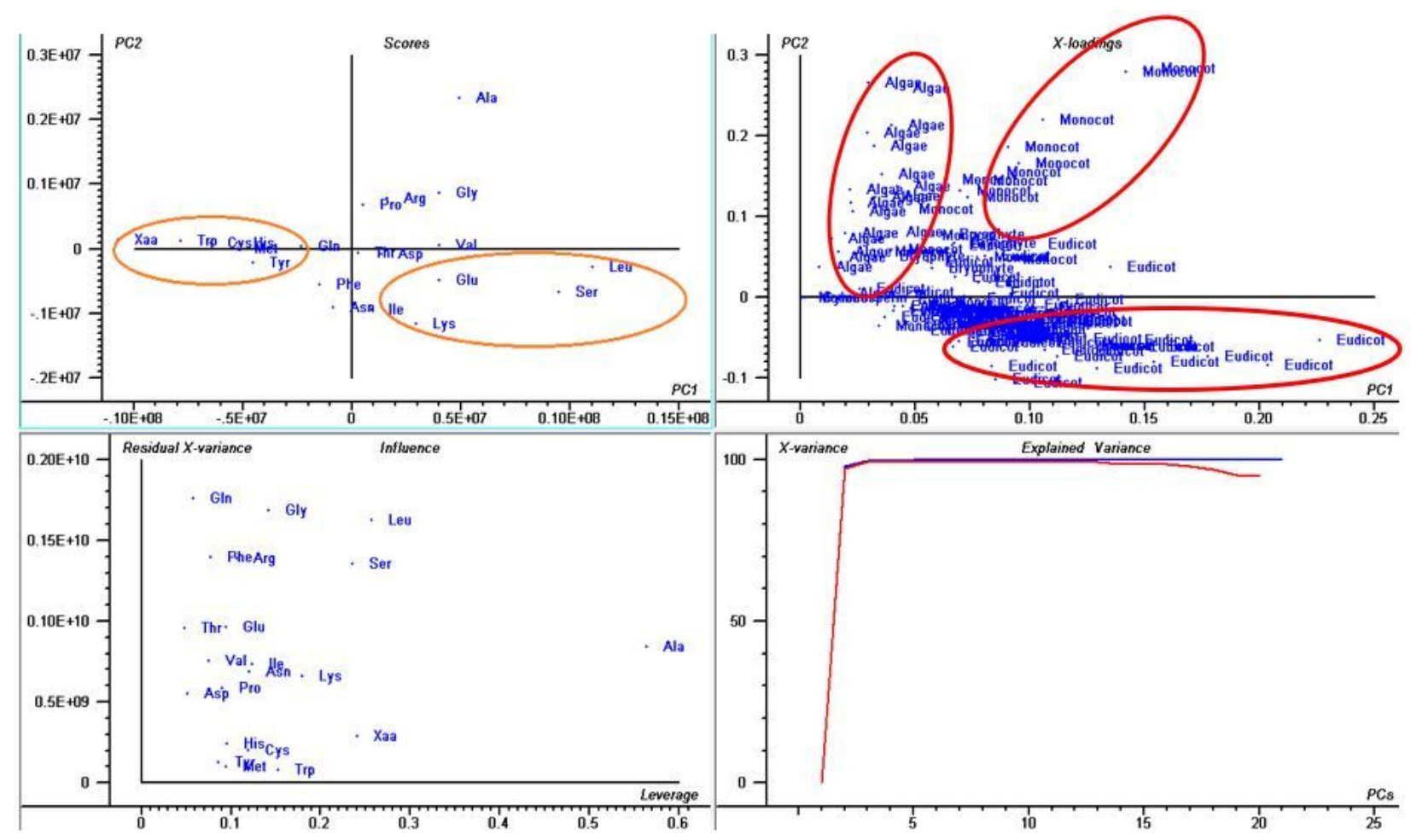

\section{Figure 5}

Principal component analysis (PCA) of amino acid abundance in plant proteomes. The PCA plot shows that Tyr, Trp, Cys, His, Met, and Xaa (unknown) amino acids are low-abundance and cluster together. The abundance of Leu, Ser, lle, Lys, and Gln was higher and grouped together. The plot shows that the abundance of amino acids is lineage specific. Algae, eudicots, and monocot plants exhibit a lineage specific correlation.

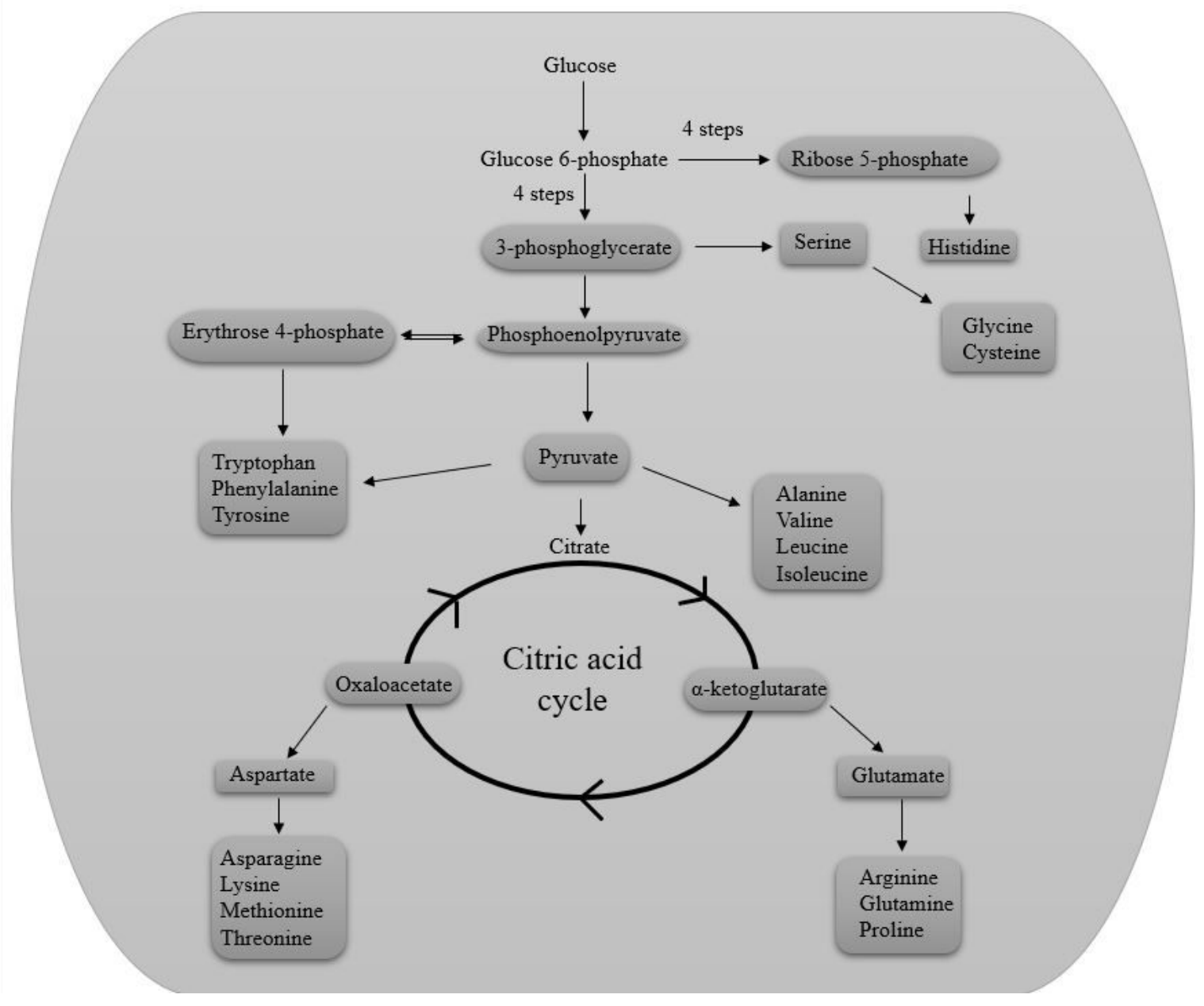


Figure 6

Schematic illustration of the biosynthetic pathway of amino acids. The abundance of aromatic ring containing amino acids is lower relative to other amino acids. The average abundance of the aromatic ring containing amino acid, Trp, is the lowest amongst others that are biosynthesized via phosphoenolpyruvate and erythrose 4-phosphate. Similarly, the abundance of Cys is relatively low compared to other amino acids. Ser is biosynthesized from 3-phosphoglycerate and Ser is subsequently used to produce Gly and Cys amino acids. The abundance of Cys is lower relative to Gly, suggesting the existence of allosteric feedback inhibition of the biosynthesis of Cys by Ser.

\section{Supplementary Files}

This is a list of supplementary files associated with this preprint. Click to download.

- supplement1.xlsx 